\title{
An application of the Delphi method of forecasting to the future of technology infrastructure in West Virginia high schools
}

\author{
William H. Carman \\ West Virginia University
}

Follow this and additional works at: https://researchrepository.wvu.edu/etd

\footnotetext{
Recommended Citation

Carman, William H., "An application of the Delphi method of forecasting to the future of technology infrastructure in West Virginia high schools" (1999). Graduate Theses, Dissertations, and Problem Reports. 3670.

https://researchrepository.wvu.edu/etd/3670

This Dissertation is protected by copyright and/or related rights. It has been brought to you by the The Research Repository @ WVU with permission from the rights-holder(s). You are free to use this Dissertation in any way that is permitted by the copyright and related rights legislation that applies to your use. For other uses you must obtain permission from the rights-holder(s) directly, unless additional rights are indicated by a Creative Commons license in the record and/ or on the work itself. This Dissertation has been accepted for inclusion in WVU Graduate Theses, Dissertations, and Problem Reports collection by an authorized administrator of The Research Repository @ WVU. For more information, please contact researchrepository@mail.wvu.edu.
} 


\title{
AN APPLICATION OF THE DELPHI METHOD OF FORECASTING TO THE FUTURE OF TECHNOLOGY INFRASTRUCTURE IN WEST VIRGINIA HIGH SCHOOLS
}

\author{
William H. Carman
}

\author{
Dissertation Submitted to the \\ College of Human Resources and Education \\ At West Virginia University \\ In partial fulfillment of the requirements \\ for the degree of
}

\author{
Doctor of Education \\ in \\ Advanced Leadership Studies \\ Phyliss C. Durden, Ed.D., Chair \\ Floyd L. Stead, Ed.D \\ Ernest R. Goeres, Ph.D. \\ Kenneth Murray, Ph.D. \\ Lawrence Jones, Ed.D. \\ Department of Educational Leadership Studies
}

Morgantown, West Virginia

1999

Keywords: Technology, Infrastructure, High Schools Copyright 1999 William H. Carman 


\section{TABLE OF CONTENTS}

TABLE OF CONTENTS __ ii

LIST OF ILLUSTRATIONS v v

LIST OF TABLES_ vi vi

ABSTRACT viii

\section{CHAPTER 1}

\section{INTRODUCTION}

Introduction 1

Statement of the Problem

Research Questions

Significance of the Study _ 6

Limitations $\longrightarrow 7$

Operational Definitions___ 8

Summary

\section{CHAPTER 2}

REVIEW OF LITERATURE

Technology Infrastructures of the Past

Effect of Technology Infrastructures

on Future School Systems

The Delphi Technique of Forecasting the Future 


\section{CHAPTER 3}

\section{METHODOLOGY}

Subjects

32

Instrument

32

Design

Procedure 34

Data Analysis

36

\section{CHAPTER 4}

\section{PRESENTATION OF THE DATA}

Introduction

37

Life Expectancy Beyond 20 Years

39

Life Expectancy of 16 to 20 Years 41

Life Expectancy of 11 to 15 Years 46

Life Expectancy of 6 to 10 Years 54

\section{CHAPTER 5}

SCENARIO, SUMMARY, CONCLUSIONS

AND RECOMMENDATIONS

Scenario

60

Time Frame Chart

61

Affordability Chart 62

Life Expectancy Beyond 20 Years 63

Life Expectancy of 16 to 20 Years 64 
Life Expectancy of 11 to 15 Years __ 67

Life Expectancy of 6 to 10 Years 71

$\begin{array}{ll}\text { Scenario Summary } & 74\end{array}$

$\begin{array}{lr}\text { Summary } & 75\end{array}$

Collection of Data _ 76

$\begin{array}{ll}\text { Treatment of Data } & 77\end{array}$

$\begin{array}{ll}\text { Conclusions } & 77\end{array}$

Recommendations — 79

WORKS CITED

APPENDIX A

Round 1 Correspondence and Response

APPENDIX B

Round 2 Correspondence and Response $\quad 92$

APPENDIX C

Round 3 Correspondence and Response _ 99

APPENDIX D

Round 2 Data Sheets 103

APPENDIX E

Round 3 Data Sheets _ 106

VITA 109 


\section{Illustrations}

\section{Figures}

5.1 Time Frame Chart 61

5.2 Affordability Chart -62 


\section{List of Tables}

4.1 Mean Life Expectancy Responses 38

4.2 Mean Affordability Responses 39

4.3 Time Frame Distribution - \#1 Staff Development 40

4.4 Affordability Distribution - \#1 Staff Development 40

4.5 Time Frame Distribution - \#2 File Servers 41

4.6 Affordability Distribution - \#2 File Servers 41

4.7 Time Frame Distribution - \#3 Wireless Networks 42

4.8 Affordability Distribution - \#3 Wireless Networks 42

4.9 Time Frame Distribution - \#4 Help Desk 43

4.10 Affordability Distribution - \#4 Help Desk 43

4.11 Time Frame Distribution - \#5 Maintenance Contract 43

4.12 Affordability Distribution - \#5 Maintenance Contract 44

4.13 Time Frame Distribution - \#6 Fiber Optics 44

4.14 Affordability Distribution - \#6 Fiber Optics 45

4.15 Time Frame Distribution - \#7 Anti-Virus Software 45

4.16 Affordability Distribution - \#7 Anti-Virus Software 46

4.17 Time Frame Distribution - \#8 Palm Computers 47

4.18 Affordability Distribution - \#8 Palm Computers 47

4.19 Time Frame Distribution - \#9 Wireless Workpad 48

4.20 Affordability Distribution - \#9 Wireless Workpad 48

4.21 Time Frame Distribution - \#10 Laptop Computers 48

4.22 Affordability Distribution - \#10 Laptop Computers 49

4.23 Time Frame Distribution - \#11 Shared Networks 49

4.24 Affordability Distribution - \#11 Shared Networks 50

4.25 Time Frame Distribution - \#12 Switched Networks 50

4.26 Affordability Distribution - \#12 Switched Networks 50

4.27 Time Frame Distribution - \#13 Voice Comm. Software 51

4.28 Affordability Distribution - \#13 Voice Comm. Software 51

4.29 Time Frame Distribution - \#14 LAN Software 52

4.30 Affordability Distribution - \#14 LAN Software 52

4.31 Time Frame Distribution - \#15 LAN to WAN Software 52

4.32 Affordability Distribution - \#15 LAN to WAN Software 53

4.33 Time Frame Distribution - \#16 Secure Comm. Center 53

4.34 Affordability Distribution - \#16 Secure Comm. Center 53

4.35 Time Frame Distribution - \#17 Network Hubs 54

4.36 Affordability Distribution - \#17 Network Hubs 55

4.37 Time Frame Distribution - \#18 Electronic Whiteboards 56

4.38 Affordability Distribution - \#18 Electronic Whiteboards 56

4.39 Time Frame Distribution - \#19 CAT-5 Wire 57

4.40 Affordability Distribution - \#19 CAT-5 Wire 57

4.41 Time Frame Distribution - \#20 Proxy Server Software 57

4.42 Affordability Distribution - \#20 Proxy Server Software 58 
4.43 Time Frame Distribution - \#21 Windows Software 58

4.44 Affordability Distribution - \#21 Windows Software 58

5.1 Occupations of Expert Panel 60

5.2 B/E Comparison - Beyond 20 Years - Life Expectancy 64

5.3 B/E Comparison - Beyond 20 Years - Affordability 64

5.4 B/E Comparison - 16 to 20 Years - Life Expectancy 65

5.5 B/E Comparison - 16 to 20 Years - Affordability 66

5.6 B/E Comparison - 11 to 15 Years - Life Expectancy 68

5.7 B/E Comparison - 11 to 15 Years - Affordability 70

5.8 B/E Comparison - 6 to 10 Years - Life Expectancy 71

5.9 B/E Comparison - 6 to 10 Years - Affordability 72 


\title{
ABSTRACT \\ AN APPLICATION OF THE DELPHI METHOD OF FORECASTING TO THE FUTURE OF TECHNOLOGY INFRASTRUCTURE IN WEST VIRGINIA HIGH SCHOOLS
}

\author{
WILLIAM H. CARMAN
}

This study investigated the technology infrastructures that will have an impact on school systems in West Virginia that desire to either retrofit existing high school structures or construct new ones. A three round modified Delphi technique was used to determine the life expectancy and affordability of each technology infrastructure.

In Round 1, surveys were sent via E-mail to 21 individuals representing public education in West Virginia at all levels, colleges and universities, technology business executives, an architect, and a foreign technology business executive. In response to the first survey, the expert panel generated a total of twenty-one different technology infrastructures that they felt could be incorporated in the building of a new high school or the retrofitting of an existing structure. In Round 2 the experts were asked the rate the life expectancy of each infrastructure on a 5-point Likert-like scale. The scale began with $0-5$ years and ended with beyond 20 years. Affordability was also ranked this time on a 6-point Likert-like scale. This scale went from beyond budget to cost effective. Eighteen of the twenty-one responded to Round 2 and Round 3. In Round 3 each panelist was sent via E-mail a copy of the Round 2 results for which the author had determined consensus. They were also given a copy of their responses and asked to either agree with the consensus or submit a reason for their original response.

A scenario was developed using time frames with comparison of Round 2 and Round 3 responses as well as responses divided by educators and business individuals. A discussion of the life expectancy compared to the affordability resulted in conclusions about which technology infrastructures were suitable to be considered by school systems.

Five categories were used to group the individual technology infrastructures for further analysis (1) Equipment (2) Networks (3) Support (4) Communications (5) Software. The percent return of surveys was $84 \%$ in Round 1, 85.7\% in Round 2 and $100 \%$ in Round 3. A total of $72 \%$ of the original selected panelists participated in the entire study. This rate of return indicated that though the individuals were involved people they were interested in education and technology in the future.

The main result of the study, although somewhat surprising, was that the technology infrastructure that was most affordable and had the longest life expectancy was "staff development". Both business and education panelists 
agreed with this conclusion strongly. They seem to be saying that all the technology you can implement into your program depends upon the training of people for success. The support category, including Staff Development, Help Desks, and Maintenance Contracts, by far was considered the most important. Secondary conclusions were that technology infrastructures would not change in the immediate future and were considered to be affordable. 


\section{CHAPTER 1}

\section{INTRODUCTION}

\section{Introduction}

School systems in West Virginia are faced with technology that is changing so rapidly that it is difficult to keep in step even if there were no financial worries. Systems are closing old, outdated buildings, renovating existing structures that are worth saving, and, in some cases, building new structures to accommodate new programs more in tune with the many technological advancements made in the last two or three decades. John Lundin in his dissertation "Contextual Determinants of Media Choice and Communication Infrastructure: A Mechanistic Perspective (Information Technology)" states:

The aggregated media choices in the organization will establish a demand for communication infrastructure. Because of this context-medium relationship, any organizational change requires a different or improved communication infrastructure due to the changes in context (Lundin, 1998).

Why is it so important that we consider new technologies when we are

planning to build new schools? Bill Gates, in his book, The Road Ahead, says:

More than ever, an education that emphasizes general problemsolving skills will be important. In a changing world, education is the best preparation for being able to adapt. H. G. Wells, who was as imaginative and fordward-looking as any futurist, summed it up back in 1920. 'Human history,'he said, 'becomes more and more a race between education and catastrophe'(Gates, 1995).

At this time let us hope that education wins the race and that educators have enough vision to see or use technology as a tool for winning. 
Have educational technologies been successfully integrated in schools? What do we consider educational technologies? These are two important questions which Marie Bissett answered in her dissertation "Investigation of Technology Integration in a Rural School District": "Educational technologies have not successfully been integrated in schools. Educational technology is mostly considered as inclusion of computers in education." (Bissette, 1998). Many different technologies are available but they change so rapidly that by the time one is purchased it is usually close to being out-of-date. Raymond Jones states in a Delphi Study at Virginia Polytechnic Institute the following:

Those technologies with a mean score of 3.00 or higher in round three were predicted to be those likely or very likely to be used in the K-12 schools of the year 2000. Two key strands of characteristics emerged: connectivity and multifunctionality. The technologies, which rated highest, had, as characteristics, the ability to be networked with other technologies and the ability to perform multiple tasks. The top five technologies were (1) desktop/laptop computers; (2) telephone access to all classrooms; (3) world wide web; (4) teacher work stations; (5) Email (Jones, 1997).

As the technologies above rapidly change component parts will also need to be changed; however, the connectivity of technologies requires infrastructure which because of economics cannot be changed very often. This presents a case for a study to look at the infrastructure which can be considered today and still may be usable in the year 2020, 2030,or beyond. Schools are built and expected to last at least fifty years. Since infrastructure is difficult to update or change, effective planning should allow the technology infrastructure to remain in place during the life of the structure. 
In June of 1998 Wayne County Schools completed construction of a brand new 18 million dollar high school that was the most costly project the West Virginia School Building Authority had ever attempted. This author, as superintendent, was faced with planning the technology for the school that was the first high school built in Wayne County since the 1950s. One of the older schools had some technology retrofit applied in the form of a centralized media management program that was interconnected with a building-wide, two-way communication system. This retrofit became a starting point for developing a technology plan for the new high school. As most plans are written, this one concentrated upon only existing technology and did not address the future very well. The architects wanted to know in the beginning of the project what kind of technology infrastructure was to be a part of the construction project. At that point brainstorming with local "experts" was the best solution available.

For this study the Delphi Method was chosen because it allowed for a variety of "expert" opinions to project ideas long range as opposed to short-term solutions. Wayne Hoy and Cecil Miskel in their book Educational

Administration: Theory, Research and Practice comment:

Problems are difficulties that can be solved by past precedents or by the application of existing policy. Dilemmas are unsolvable within the existing framework. Because dilemmas are endemic to organizations, they serve as perpetual sources of change. Any futuristic study which attempts to identify concerns or problems, then, would be representative of dilemmas in that there is no past precedent or existing policy available for their resolution (Hoy and Miskel, 1996).

In his dissertation "An Application of the Delphi Method of Forecasting to Nursing Education Planning in West Virginia" Dr. Larry Stead writes: 
Educational Planning and policy decisions must incorporate the use of forecasting tools for the purpose of continually conducting and assessing studies of the future.

One of the troublesome features of the future is that it has not occurred. Data available from studies of the past are not always applicable in studies of the future. There are no future facts accessible in the present; therefore, much of the information about the future must be produced and assembled from the judgments of experts or other persons knowledgeable in areas related to specific research interests. The Delphi technique is one way of looking at the future.

The Delphi technique is characterized as a member of forecasting tools; it is one of several intuitive forecasting methods. Typically, the procedure includes a questionnaire mailed to respondents who remain anonymous to each other. Respondents first generate several rather concise statements of events, or in some cases, start out with the events already stated for them. In the second round, respondents are asked to give estimates as to the probability of each event occurring at a given date in the future. Once the respondents have given their initial responses, the responses are collated and returned to each respondent who then is invited to revise his estimates. These third round responses are made with the knowledge of how others felt regarding the occurrence of each event. If a respondent's estimate does not fall within the interquartile range of all conjectures, he is asked to justify his position, whether or not he wishes to change his position (Stead, 1975).

Instead of focusing on technologies, this study will focus on the infrastructure which supports these technologies. The identified infrastructures should remain in place for a long period of time while the technology devices are switched-out as they become obsolete. The study will help West Virginia school systems be costeffective with the dollars currently being spent and yet remain on the leading edge of technology for many years. 


\section{Statement of the Problem}

Using the Delphi method of forecasting, this study provided information from an expert panel about the types of technology infrastructure that can be considered for the construction of a new high school or the renovation of an existing structure. The panel has forecasted the life expectancy of the technology and its affordability to a school system.

\section{Research Questions}

1. Will the expert panel be able to list as many technology infrastructures as possible that could be implemented in the construction of a new high school or the renovation of an existing structure? (For the purpose of this study the term infrastructure was used in a broad sense).

2. Will the expert panel be able to consider each of the technology infrastructures listed and decide on how long these will still be viable technologies?

3. Will the expert panel be able to consider each technology and determine how affordable the technology is for implementation in West Virginia schools? 


\section{Significance of the Study}

This study has provided information from an expert panel on the types of technology infrastructure which can be considered today, the life expectancy of such infrastructures, and the economic impact on West Virginia school systems. By identifying what experts believe to be the infrastructures that will have longevity and be affordable to school systems, the decision-makers in the educational setting can be better prepared to spend taxpayers' dollars. Since West Virginia does not have an overabundance of capital available for the construction or renovation of high schools and their related infrastructures, monies should be expended in a manner that would last over a long period of years for the best interest of students. Information from this study is valuable to taxpayers, teachers, principals, superintendents, boards of education, state department employees, the state superintendent, the state board of education, the school building authority, and the state legislature as the unit we know as "school" may be considerably different in the future.

If home schooling and charter schools continue to grow, then public schools must have leading-edge technology to keep pace. It is technology that allows the home school market to have the resources available without the overhead costs associated with public schools.

For public schools to remain on the leading edge of technology, infrastructure in these schools must be able to remain for a period of many years. In that way monies can be spent on new technologies instead of always updating infrastructure. 


\section{Limitations}

This study is limited to data collected from January to March of 1999 through a panel of experts made up of college professors, West Virginia Department of Education administrators, West Virginia School Building Authority administrators, private sector executives, local school system administrators, architect school level technology administrators, and a foreign corporation executive. All participants on the panel have at least twenty years of experience in their fields. No geographic consideration was given to the selection of the panel. Members were selected because of their positions and perceived knowledge in their fields.

Much care was taken in the selection of the panel, but that does not preclude the possibility that there are other persons who could have given meaningful input to this study. The panel was limited to approximately twenty-five individuals most of whom resided in West Virginia. Some, especially in the private sector, resided and worked outside of West Virginia; their opinions should help balance the study. This researcher is confident that the variety of panelists has provided data that reflects current technology infrastructures. If more time and finances were available, the panel could have been expanded to provide even more variety. Since the Delphi uses consensus to draw conclusions, extreme ideas do not effect the results of the study. These results are a consensus of the panel and should not be misinterpreted to be the entire range of possibilities for the future. The researcher reserved the right to determine when consensus had been reached; however, the use of a 6-point and a 5-point Likert-like scale aided the process. 
Since misinterpretations or misunderstandings of the instructions could jeopardize the results of this study by panel members, every effort to minimize these possibilities was taken. Both evening and daytime phone numbers, fax number, mailing address and E-mail address of the researcher have been made available to the panel members for contact if a problem arose. The results of the study are only as accurate as the thoughtfulness, honesty, and accuracy of the individuals completing the survey.

Each panel member received an E-mail one week before the actual survey was sent making him or her aware of the importance of returning the survey within the timeline. Additional contacts were made with those who failed to respond in a reasonable time. A return rate of $100 \%$ during round one of the Delphi study was achieved. Twenty-one of the original 25 panelists continued to round two and received surveys. The response rate to the round two surveys was $85.7 \%$. Each of these panelists were given an opportunity to compare their responses to the consensus and either agree or support their original response.

\section{Operational Definitions}

Affordability - The degree to which a school can afford a particular technology. The range is from Cost Effective to Beyond Budget.

Delphi Technique - The Delphi Technique is the systematic assembling of a set of expert judgments about the likelihood of specific occurrences (events) in the future by designated time frames, impact of the occurrence, desirability of the occurrence, and reasoning behind the lack of consensus (Stead, 1975). 
Delphi-Round 1- Round 1 is the first issuance of the Delphi Technique designed to generate and identify events which the panel of experts believe have a fifty percent probability of occurrence (Stead, 1975).

Delphi-Round 2 - Round 2 of the Delphi technique represents the initial followup or feedback in which the panel of experts provides their initial responses to (1) the time frame in which each event will probably occur; (2) the desirability of the event, should it occur; and (3) the impact of the event, if it occurs (Stead, 1975). Delphi-Round 3 - Round 3 of the Delphi technique is designed to refine, through group consensus, the time frame of each generated event and to provide the opportunity for each member of the group to explain any difference of opinion (Stead, 1975).

Desirability - Desirability is defined as something seen as beneficial or something that someone is eager to obtain. High desirability is defined as a mean desirability rating which equals or exceeds 3.50 on a six-point Likert scale. Low desirability is defined as a mean desirability rating between 1.00 and 3.49 on a six-point Likert scale (Stead, 1975).

Expert - An expert for this Delphi application is any one of the approximately twenty-five persons selected for the panel on the basis of their position and knowledge of technology and infrastructure.

Forecast - A forecast is an opinion or estimate about a future happening or condition (Stead, 1975). 
Impact - Impact is defined as the degree to which an event will result in having a significant effect upon installations of technology infrastructures in West Virginia public schools.

Infrastructure - Infrastructures are those technologies which support the user technologies and are thought of as permanent installations. For the purpose of this study a broad definition is necessary and must not be limited to wiring and traditional technologies.

Life Expectancy - The particular Time Frame assigned to a technology infrastructure. For this study the Time Frames include 0-5, 5-10, 11-15, 16-20, and $20+$ years.

Likert Scale - A Likert scale is defined as an ordinal measurement which assigns points to five or more categories measuring responses in a questionnaire (Stead, 1975).

Likert-like Scale - A modified Likert scale in this study used either five or six categories.

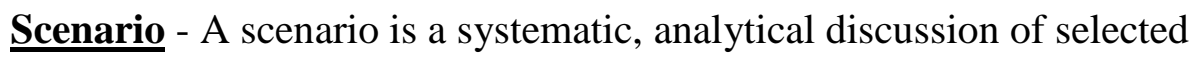
occurrences (events) by designated time frames representing short- range, intermediate-range, and long-range forecasts in conjunction with an impact/desirability rating (Stead, 1975).

Technology - These are devices which eliminate or seriously reduce the need for manual labor to accomplish a task. These devices are not restricted to computers or computer-like appliances. 
Time Frame - The length of time used to describe the Life Expectancy of a technology infrastructure.

\section{Summary}

An introduction to the research that has taken place is presented in this chapter. The need for technology and technology infrastructures to be researched has been shown as well as the need for school systems which are building new schools to look to the future so that they do not build obsolete structures with regard to technology. The Delphi technique has been used to project which infrastructures should be considered in a serious manner. Forecasting in this manner does not give absolute solutions, but does provide systems with a welleducated chance of choosing the infrastructures which have the best chance of enduring.

In chapter 2 three strands of literature review are discussed:

- Technology infrastructures of the past

- The effect of technology upon future school systems

- The Delphi technique of forecasting the future.

Chapter 3 presents the methodology used in the study.

Chapter 4 presents the collected data using charts.

Chapter 5 presents the scenario, summary, conclusions and recommendations. 


\section{CHAPTER 2}

\section{REVIEW OF LITERATURE}

\section{TECHNOLOGY INFRASTRUCTURES OF THE PAST}

To help the readers who may not be aware of how technologies have developed, this chapter will begin with a review of the literature which traces the history of technology development. Although many of the discussions may not pertain to infrastructures, as we know them today, they were the infrastructures of yesterday. For example the networking of computers in schools is a fairly recent technique.

Bill Gates says it best when we are looking back at technology.

Success is a lousy teacher. It seduces smart people into thinking they can't lose. And it's an unreliable guide to the future. What seems the perfect business plan or latest technology today may soon be as out-of-date as the eight-track tape player, the vacuumtube television, or the mainframe computer (Gates, 1995).

In a Delphi Study conducted in 1988, Peggy O'Donnell found that:

Traditionally, teachers have used books, paper, pencils, workbooks and the chalkboard to teach the curriculum. Since the 50's a variety of audio-visual materials have been added. More recently, the use of new tools and materials has increased (O'Donnell, 1988).

The above study went on to list microcomputers, VCR's, interactive video and CD ROM as technologies which might impact the future classroom. The 
respondents also expressed concern in varying degrees over equal access to technology and the growth of educational technologies. (O'Donnell, 1988)

Another Delphi Study conducted in 1984 was titled "Making Our Schools More Effective" and used six categories for input. One of the categories was "curriculum materials" and there was no mention of technology. Instead everything was centered about textbooks and their associated programs (Mann \& Lawrence, 1984).

Bill Gates said:

The claim that information would define the future reminded me of the famous party scene in the 1967 movie The Graduate. A businessman buttonholes Benjamin, the college graduate played by Dustin Hoffman, and offers him a single word of unsolicited career advice 'Plastics.' I wondered whether, if the scene had been written a few decades later, the businessman's advice would have been: 'One word Benjamin. Information' (Gates, 1995).

The next question is how the information is presented. Is it in written form in books? Are there better ways of presenting information?

During World War II a calculating machine which took advantage of the binary expression was built. Its name was Electronic Numerical Integrator And Calculator (ENIAC) and its purpose was to speed up the calculations for artillery-aiming tables. ENIAC weighed 30 tons and filled a large room. By the early 1960's transistors replaced vacuum tubes and in the 1970's the microprocessor arrived on the scene. Today, many toys have "chips" in them that are more powerful than the 70's microprocessor. In 1975, a company named "Microsoft" was formed and since has dominated the world of software and guided the direction of microcomputer development. In 1980, 
Microsoft joined with I.B.M. and created MS-DOS, an operating system for the personal computer. Three years later Microsoft announced a graphical interface for the personal computer, which was called "Windows" (Gates, 1995).

In today's world Microsoft is being sued because of its alleged monopoly for accessing the Internet. A more accurate representation would be that Microsoft has maintained a vision of the future that has allowed them to shift their focus many times and thus remain ahead of the competition.

Marvin Cetron and Margaret Gayle, in the book Educational Renaissance that was written in 1991 observed:

As the 1990's open, a variety of new and newly useful technologies are also promising to transform our nation's classrooms. Among these are computer networks, interactive CD-ROM, "distance learning" - courses presented at a central location and delivered to schools by satellite transmission, microwave relay, or fiber-optic link - and the old-fashioned television (Cetron \& Gayle, 1991).

Many of the above technologies have been tried with varying success.

What Cetron and Gayle say about technology in the classroom sums up the situation very well.

Given all the success stories in which computers and other gadgetry have promoted learning, saved students from dropping out, and even saved whole schools from academic collapse, it seems likely that the average classroom a decade hence will be outfitted with all the high-tech conveniences that ten more years of development will offer. We certainly would like to make that forecast, for little seems more certain than that computers and telecommunications, in the hands of teachers who know how to use them effectively, could go a long way toward solving many of the problems that now beset our schools. Yet the reality is that while educational television and videodiscs will proliferate as quickly as schools can adapt to them, we cannot guarantee that computers will do the same (Cetron \& Gayle, 1991). 
It appears that Cetron and Gayle should have been more convinced about the proliferation of computers as it now appears computers are everywhere even in classrooms.

In 1971, Harry F. Silberman, in a speech entitled "Some Reservations about the Application of Technology to Increase Productivity in Education," raised three issues on the prospects of converting education from a labor intensive to a technology intensive enterprise: 1) how technology might affect the quality of education; 2) the relationship of technology to equality in education; and 3) the transitory nature of technological innovations. The question of equity is viewed as one of the most critical issues and the least amenable to a technological solution (Silberman, 1971). The issue of equity is important as we discuss the infrastructures that will be implemented in new high schools as well as renovated high schools. Without equal infrastructures there is no equity in technology. The chain is only as strong as its weakest link and, in the case of technology if the infrastructure is weak then it does not matter what technology is added.

Two years later at a conference dedicated to E. F. Lindquist the focus was on the three areas in which Lindquist pioneered: the development of test of educational achievement, design and analysis techniques in educational research, and an application of electronic data processing to educational problems (Coffman, 1973). Looking at the last area one can see a term "electronic data processing" which is used sparingly today. 
In the same year an article in Computers and the Humanities featured a discussion of computer assisted instruction as an effective teaching method with more and faster learning, as opposed to the cost-effectiveness question. (Allen, 1973) Again, technology seems to be the answer to some of the educational questions of that time. In "Computer Technology: Key to the Future?," Harold E. Mitzel, stimulated by the slow-paced adaptation of computers to education tasks, discusses some of the incentives and constraints that operate on computer application to instruction (Burdin, 1974).

Public education was not the only group struggling with technology as a solution to some of their problems in the 1970's. The colleges and universities were also looking for help with their problems. "The basic problem today is that income growth is slowing, and unless colleges and universities reduce expenditures growth to correspond with income growth, they will incur deficits. Colleges and universities need management assistance. The 3 major areas of management concern for the 1970's are: statewide planning, the process of governance and management, and production technology" (Millett, 1974). Once again, technology appears as a possible solution to an educational problem.

In the early 70's a small team of experts consisting of an architect, an engineer, an economist, and C. W. Phillips visited a number of countries looking at many different types of school building systems. Their major objective was to identify for policymakers the considerations involved in using to the best advantage industrialized building methods for the 
construction of schools. Upon return, C. W. Phillips reflected on three related issues which appear to preoccupy a great many of those charged with the responsibility of school building provision: industrialized building systems, educational objectives, and the problem of change (Phillips, 1974). The problem of change brings to the front how technology is going to be a part of the changing educational system. As the team was looking at industrialized building methods this author wonders how many different technology infrastructures entered their discussions.

"Education is tumbling aimlessly into a future in which the greatest acts of immorality will be those in which technological change occurs without thorough examination of consequences." (Olsen, 1974) Olsen is stating a reality that was true in the 1970 's and is also true as we approach the $21^{\text {st }}$ century. This study is an attempt to examine technological change and look at some of the consequences that might occur.

In 1981 a research project at Rutgers University investigated three perspectives on the future of science and technology and their relevance to educational theory and practice. The three were the Managerial Rational Perspective, the Humanistic Perspective, and the Ecological Perspective. In the Managerial Rational Perspective science and technology are the most important factors by which the future will unfold. The Ecological Perspective sites problems such as pollution, resource depletion, and social disruption. The Humanistic Perspective is a middle path between the other two and looks at agendas that the scientists tend to consider irrelevant (Potter, 1981). 
As in the 1970's, the concern for technology goes beyond the hardware, software and infrastructures that can be used. There is a real question as to whether or not technology is a viable solution for the future. It appears to be one of the solutions; however technology must be implemented and integrated with other possibilities.

At the University of Oklahoma an ethnographic study concluded that:

Much of the research in educational technology is concerned with the strategies of learning and the development of intellectual skills. The futurists believe that this is a potentially productive endeavor for research activities. Educational technology needs to investigate alternate ways of using the capabilities of technology in providing educational services to nontraditional students in nontraditional settings (Dillon, 1980).

Nontraditional students in nontraditional settings, does this point towards charter schools, home schools, or other practices that we have yet to experience? It does illustrate that the educators must think beyond their own box or the boxes, which have been illustrated for them.

Finally, for technology of the past, a study done at Carnegie-Mellon Universtiy in 1990 directs its attention to computer software that might be considered an infrastructure.

Since the modern electronic digital computer first began to proliferate in the fifties, computer software has been plagued by problems of quality, productivity, reliability, and efficiency. A general model of technological development is proposed which postulates two distinct aspects of development - cyclical technical breakthroughs and an evolving infrastructure of supporting institutions and social processes. The supporting infrastructure has suffered from the lack of a clearly appropriate disciplinary model and from the difficulty inherent in attempting to standardize terminology, artifacts, and practices involving an abstract medium (Shapiro, 1990). 


\section{EFFECT OF TECHNOLOGY INFRASTRUCTURES ON FUTURE SCHOOL SYSTEMS}

It has been illustrated that the experience of the past is not necessarily an example for success in the future. Many technologies and infrastructures, while functional, have given way to other systems that the public seems to want. The 8-track stereo gave way to the cassette tape system, vacuum tubes gave way to transistors and now cassette systems are giving way to $\mathrm{CD}$ technologies. In 1991 Marvin Cetron and Margaret Gayle predicted:

Yet the reality is that while educational television and videodiscs will proliferate as quickly as schools can adapt to them, we can not guarantee that computers will do the same. ... In fact, it has never been easy to fit computers into the classroom. Computers are meant for single users. Even where many terminals are linked to a huge mainframe, only one person at a time can work at the terminal. Yet classrooms are group-oriented and are fast becoming more so. The most innovative and successful schools today are adopting team learning. ... In that environment, a computer on every desk could turn out to be as useful as the sand from which its chips were made (Cetron, 1991).

Almost a decade since Mr. Cetron wrote the above, schools are still struggling to place computers in classrooms and spending thousands of dollars on current infrastructure. In retrospect however, videodiscs and educational television have not proliferated as quickly as once thought. What is the future of public education?

Marvin Cetron would direct us to Mortimer Adler's Paideia proposal as a promising and comprehensive effort:

- All children are educable. They deserve not merely the same quantity of schooling, but the same quality, the best education for the brightest children being the best for all. That rules out most 
electives, and especially vocational programs that spend valuable class time on job training instead of devoting it to the cause of a sound basic education.

- Each student's achievement must be weighed against his or her own capacity to learn, not compared with the performance of others. Thus, letter or number grades are replaced by extensive written critiques of the student's performance.

- American schools should prepare their students to earn a decent living, to be good citizens of the Republic, and to make themselves a good life. In part because of this, schooling must give them a good start on the lifelong process of becoming generally educated, and schools must be judged on how well they accomplish this task.

If those were some of the ideas for changing the direction of education in the early 90s, what is being suggested today? Bill Gates is one of the foremost experts on the future of technology as his company continues to set the standards. In Chapter 9 of Looking Ahead, entitled "Education:

The Best Investment," Gate's says:

Great educators have always known that learning is not something you do only in classrooms, or only under the supervision of teachers. Today it is sometimes difficult for someone who wants to satisfy his curiosity or end his confusion to find the appropriate information. The highway is going to give us all access to seemingly unlimited information, anytime and anyplace we care to use it. It's an exhilarating prospect, because putting this technology to use to improve education will lead to downstream benefits in every area of society.

There is an often-expressed fear that technology will replace teachers. I can say emphatically and unequivocally, IT WON'T. The information highway won't replace or devalue any of the human educational talent needed for the challenges ahead: committed teachers, creative administrators, involved parents, and, of course, diligent students. However, technology will be pivotal in the future role of teachers (Gates, 1995).

Seven years before Gates wrote his book a Delphi study conducted by Peggy O'Donnell suggested some of the same directions when addressing the classroom of the year 2000: 
Technology is expected to have great impact on the classroom of the future, not only in terms of what the classroom will look like, but also on the activities that will take place in it. The computer and interactive video, in particular, are expected to allow smaller group projects emphasizing cooperation, critical thinking and problem solving. Independent learning projects will let children learn at their own pace. Ideally, the teacher will monitor all these activities centrally, intervening when necessary. While respondents felt that technology will play an important role in the classroom of the future, they also stated that the teacher would remain in control of the classroom. It is the teacher's creative use of new technology that will enhance the teaching and learning process, but books and other traditional learning materials such as filmstrips and audiotapes will also continue to be important (O'Donnell, 1988).

Further insight into the future of schools can be gotten from some presentations at Building Industry Consulting Services International (BICSI: A Telecommunications Association) conferences. Networks and their speeds are a hot topic and have a lot to do with the future of technology and the infrastructures needed. In the 1998 fall conference one of the presentations was entitled "The Greed (Need?) for Speed". Some future directions can be gleaned from this presentation.

We'll have infinite bandwidth in a decades time. So stated Bill Gates in an article in the October 11, 1994 edition of PC Magazine. But more than a few eyebrows were raised a year earlier, in 1993, when George Gilder introduced the concept of Metcalfes law, which states that performance of a network grows by the square of the number of devices attached, implying a tripling in bandwidth every year! In light of these bold predictions by such industry notables, it would appear at first blush that any network manager not already planning for Gbps demands to the desktop might be viewed as being asleep at the wheel (Bartolutti, 1998).

There exists a drive for more speed among those responsible for Wide Area Networks (WAN) and as a result high performance single-mode fiber is being used. Digital voice traffic is physically limited by the number of people 
in the world and how long they talk on the phone. Data traffic does not have the same limitation especially with Internet traffic doubling every four-six months. Voice traffic is estimated by Forrester Research to make up less than $1 \%$ of the worldwide total within seven years. Data rules!

Conversely, Local Area Networks (LAN) in today's environment do not require additional speed. In five years, it is less clear and beyond five years the picture gets clouded even more. (Bartolutti, 1998)

All that being said, what about the supporting infrastructures? What is the best strategy if you are installing backbone wiring? According to a 1996 Business Research Group study, cited in Bartolutti's presentation the above bandwidth improvements can be done over existing cabling infrastructures. In the LAN environment high performance UTP will be preferred (69\%) to fiber optic (10\%). This should last through the year 2000. Beyond 2000 the speeds may justify the instillation of high performance cabling systems.

Infrastructures over the same time period will use high performance UTP at the LAN level, multi-mode fiber moving to single-mode fiber in the building backbone, and single-mode fiber in the campus. (Bartolutti, 1998)

An additional opinion was offered at a similar conference in Germany addressing the implication on LAN and cabling system design. Pier Luca Montessoro, Associate Professor, Universita degli Studi di Udine explained:

Users will be satisfied at the LAN level with a shared link (10Mbs.), a dedicated (switched) link (10Mbs.), or a shared or switched link (100Mbs.) as 
humans can not handle data any faster. This does not allow low quality

cables to be used, but anything exceeding a (good) CAT-5 cable is

unnecessary. The backbone in the computer room must be supported by high quality copper or (better) optical fibers (Montessoro, 1998).

In an article entitled "Why Bring the Internet into the Classroom?", researchers Patricia Kusimo, Carolyn Carter, and Marian Keyes looked at technology in Tennessee schools during the 1996-97 school year and drew the following conclusions:

While the Internet can create more "teachable moments," it also calls for different instructional strategies, greater flexibility, and more willingness to follow student interest and facilitate student exploration. Student and teacher accounts argue that the Internet provides more timely information and allows for more authentic learning tasks than do texts.

Although teachers had expected to have adequate Internet access during the study, in practice, access varied among schools according to the number of Internet accounts per classroom, the Internet provider, available search engines, and other factors.

Long lag times, shutdowns, or freeze-ups of systems sometimes disrupted lesson plans (Balow, 1998).

The above study points out the necessity of strong, reliable infrastructures to be in place so the use of specific technologies, such as the Internet, can be successful. The author also points out that "Clearly, using the Internet in the classroom does not guarantee good curriculum or teaching practices." (Balow, 1998). This last observation leads educators to the conclusion that schools need to be careful when selecting technologies or infrastructures that the appropriate reasons support the selections. 
In an update of the National Coalition for Technology Education and Training's (NCTET) 1994, "National Information Infrastructure Requirements for Education and Training,"

A 1997 report describes the extent to which the four established national goals for technology in education (professional development, access to technology, connectivity to the information superhighway, and technology-based learning resources) have been implemented. The NCTET has added a fifth goal to address the need for support implemented in a timely and equitable manner (EDRS, 1997).

Once again infrastructure plays an important role in the future of education. Gerald Bailey, in a September 1997 article in Learning and Leading with Technology, states that "School administrators consider themselves technology leaders, but few would claim they know all there is to know". Bailey also examines 10 concepts for technology integration in $21^{\text {st }}$ century schools and in them includes "technology planning, ethics, infrastructure, technical support, and technology leadership" (Bailey, 1997). Another look into the future found an article by David Arnold that again makes infrastructure an important piece of the planning puzzle.

The Lowell, Massachusetts, district technology administrator and team have assumed responsibility for determining the specifications and selection of equipment. Joint discussions with the architect are held to develop appropriate infrastructure and educational spaces (Arnold, 1997).

This research study includes an architect on the expert panel to include this prospective on the planning of technology as a retrofit or a new construction of a high school. Katie Hickox, in a 1997 Electronic Learning article, examines technology trends that will make the most difference in schools in the $21^{\text {st }}$ century. 
- Infrastructure needs (public and private funding)

- CD-ROM's versus software download from the Internet and bandwith

- Appliance, or single-use, versus multipurpose computers

- Virtual classrooms

- Technology training for teachers (Hickox, 1997).

The future of technology implementation depends upon the infrastructures established today. School systems are unable financially to update the technology infrastructure that was installed in new buildings or retrofitted in older buildings.

A recent Delphi study conducted by Carl Friebel a scenario is created which includes the following statements:

Technology will not only support and enhance the delivery of curriculum, but will, along with problem solving and access to data bases, become an educational focus.

Other events likely to occur between 2001 and 2010 include the networking of all schools by computer for curricular use, computer connections between home and school, and the use of two-way cameras to allow for interaction between teacher and student in different locations. It is also projected that voice recognition software will become sophisticated enough to virtually eliminate the need for keyboarding skills.

Between 2011 and 2020, hard copy, paper textbooks will be replaced by electronic texts. These electronic texts will be stored on small, portable, computer notebooks.

After 2020 computer software will reach a level of sophistication that will enable the use of avatars in the teaching/learning process. Avatars will be teaching resources only, and will never replace the classroom teacher in the delivery of instruction (Friebel, 1999).

The consensus seems to be that the future of technology in schools is going to require a solid infrastructure for support and those technologies will not eliminate the need for teachers and administrators. 
In February 1999, the President's Information Technology Advisory

Committee submitted a report entitled "Information Technology Research:

Investing in Our Future" that contained the following findings and recommendations:

Findings:

1. Our Nation's dependence on the Internet as the basis for its information infrastructure continues to grow at a dramatic rate.

2. The Internet is growing well beyond the intent of its original designers, to such an extent that we no longer understand it and cannot confidently continue to extend it.

3. Learning how to build and use large, complex, highlyreliable and secure systems requires research.

Applications:

1. A National Digital Library

2. The Next Generation World Wide Web

Recommendations:

1. Fund research in the behavior of the global-scale network and its associated information infrastructure. This should include collecting and analyzing performance data as well as modeling and simulating network behavior.

2. Support research on the physics of the network, including optical technologies, wireless technologies including satellites, wired technologies including cable, and the related bandwidth issues.

3. Fund a balanced set of test beds and research infrastructure that serve the needs of networking research as well as research in enabling information technologies and advanced applications (PITAC, 1999).

In the committee's findings and recommendations the term infrastructure in relation to technology is found more than once. The committee is urging that research funds be made available to look at technology infrastructures. 


\section{The Delphi Technique of Forecasting the Future}

The Delphi technique was chosen for this study because of the necessity to predict the future as accurately as possible. As early as 1975 Dr. Floyd Stead, in his doctoral dissertation, wrote:

One of the most recent forecasting tools in educational planning and decision-making is the Delphi technique. The Delphi technique was originally developed by the RAND Corporation for obtaining greater consensus among experts about urgent defense problems without face-to-face discussion. The RAND Corporation has performed a number of studies employing the Delphi technique. One example was its use in conducting an extensive survey in forecasting long-range developments, some as far as fifty years into the future, in such areas as scientific breakthroughs, population growth, automation, space progress, probability, and prevention of war and future weapons systems (Stead, 1975).

Delphi studies use a panel of experts who are identified as being knowledgeable in the areas being studied. The experts are asked a series of questions about the likelihood of certain events occurring. The answers to the questions are returned to the investigators for their review and refinement of the original set of questions. This process is repeated two times between the investigators and the original experts as a means of clarifying and narrowing the focus of the responses so that a more precise set of conclusions can be drawn about what the experts think. Since face-to-face interaction is not a requirement, the Delphi technique could be used with groups that would not ordinarily meet together. If used with the uninformed, however, the results of a Delphi study will likely be unsatisfactory (Flinchbaugh, 1993). 
The advantages to the Delphi technique include: (1) opportunities for large numbers of people to participate; (2) anonymity for participants which makes the contribution of ideas a safe activity; (3) free of social pressures, personality influences, and dominance by individuals; (4) opportunities for participants to reconsider their opinions; (5) allows information sharing and reasoning among participants; (6) conducive to independent thinking and gradual formulation; (7) provides a varied and well-selected respondent panel;

(8) can be used to reach a consensus among hostile groups, and (9) is inexpensive (Webber, 1995; Stead, 1975).

Among the disadvantages of the Delphi technique are the large amounts of time required to conduct several rounds, the complexity of data analyses, the difficulty of maintaining participant enthusiasm throughout the process, and the problem of keeping statements value free and clearly defined (Webber, 1995).

The Delphi technique has been used to assess the future of technology in education through the use of various expert panels. Shelia Ann Colley Christy wrote in 1997 that her ". . study attempted to create a link between CNTs (Computer Network Technologies) experts and school Technology directors in order to determine which of the predicted CNTs developments were appropriate and feasible for the K-12 educational environment. Using the Delphi technique, CNTs experts indicated what future CNTs would emerge over the next three to five years. This study found that much of the CNTs developments predicted by CNTs experts were rated as highly appropriate and highly feasible by school technology directors. However, there was a common thread of concern by the school technology directors regarding 
technology juggling, which was commented on through-out Phase II's survey

(Christy, 1997).

In a study by Raymond Thomas Jones in 1997,

The Delphi technique was used to gather predictions from an expert panel of teachers, administrators, electronic media specialists, and those working in the technology industries. . . Towns such as Blacksburg, Virginia, are now being called "electronic villages" with electronic infrastructure which not only ties together all aspects of the town but also connects the town to the world. . Two key strands of characteristics emerged; connectivity and multifunctionality. The technologies that rated highest had, as characteristics, the ability to be networked with other technologies and the ability to perform multiple tasks. The top five technologies were (1) desktop/laptop computers; (2) telephone access to all classrooms; (3) world wide web; (4) teacher work stations; (5) Email (Jones, 1997).

Sandra Ramos Miller wrote in 1995:

The purpose of this (Delphi) study is to identify trends and events that are likely to occur between now and the year 2005 that will have an effect on what children will learn (the content of curriculum) and how technology will be used to help children learn (the delivery of instruction) among elementary students ages five to eleven in American public schools. . . Data were collected using fax and e-mail technology. . . The trends or events most likely to influence the technological delivery of instruction include: computers in classrooms for information acquisition and delivery, disparity in wealth among schools and students, technology that allows teachers to design multimedia lessons and individualize instruction, schools linked together through audio/video communication, a national information infrastructure, and miniaturization of technologies. . . Technology will continue to offer unlimited opportunities for new types of instructional delivery, but disparity in wealth will effect the access of elementary students to these benefits. . . A technological infrastructure will need to be developed to close the "technological gap" between affluent and less affluent schools (Miller, 1995).

A Delphi study was conducted by Terry John Quist in 1997 in rural

Minnesota. He found:

Panel members reached consensus on all of the change scenarios that they had identified as possibilities for expanding educational 
opportunities. In part, the panelists agreed that: (1) Integrating technology with learning will create more educational opportunities for students in the next five years; (2) Minnesota's Graduation Rule and newly authorized statewide testing initiative will result in changes in educational opportunities; (3) Rural schools in the next five years will become community centers offering expanded opportunities and services for students and community members (Quist, 1997).

During the late fall of 1998 and the early winter of 1999 Carl Friebel conducted a Delphi study looking at the "Future of Public Education in West Virginia". When organizing his scenario, seven long-term trends were identified and one of them was:

... (5) technology will play an increasing role in the education process; ". One of the secondary events "All schools will be networked via computers." He further concluded: "The everincreasing infrastructure and number of Internet connections in the schools will serve as the foundation for the occurrence of this event. Students in diverse locations will be able to work on assignments and share information electronically, expanding their capabilities and understanding of technological applications (Friebel, 1999).

\section{Summary}

During the search of the literature it was difficult to find studies that dealt specifically with the idea of technology infrastructures. However, it was reassuring to note that the president's panel is recommending large budgets to support research in this area.

The above studies are a few examples of the many Delphi Studies, which have been conducted by researchers. The Delphi appears to be the research technique of choice when looking into the future. This type of study is an efficient and cost effective process to use when collecting data from experts whose calendars are difficult to organize for meeting purposes. The studies in 
this chapter are specific examples of the application of the Delphi technique to the subject of technology and technology infrastructure. 


\section{CHAPTER 3}

\section{METHODOLOGY}

\section{Subjects}

The subjects of this study consisted of approximately twenty-five individuals who constituted an expert panel. These individuals each had a minimum of twenty years of experience in their field and were in executive or administrative positions. The panel was made up of a variety of individuals selected for the positions they hold and their knowledge of technology in school settings. The panel consisted of state department administrators, building authority administrators, private sector executives, local school system administrators, an architect, school level technology administrators, and one foreign executive.

\section{Instrument}

Survey instruments were constructed for each of the three rounds of the Delphi technique. In the first round, the respondents were given a survey in which they were asked to identify technology infrastructures that could be considered in the construction or renovation of a high school in 1999. The second round survey presented a synthesized list of responses from the first round and a five-point Likert-like scale used to determine the projected life expectancy of an infrastructure. The time frames for the life expectancy questions were: (a) 1-5 
years; (b) 6-10 years; (c) 11-15 years; (d) 16-20 years; and (e) beyond 20 years. For the purpose of data synthesis the following values were assigned to the letters: $\mathrm{a}=5, \mathrm{~b}=4, \mathrm{c}=3, \mathrm{~d}=2$, and $\mathrm{e}=1$. If it was the belief that a technology would never be implemented, the 1-5 years category was selected.

In addition, a six-point Likert-like scale was used to determine the affordability of each item. The categories of affordability were (1) Beyond Budget (2) Very Expensive (3) Expensive (4) Affordable (5) Very Affordable (6) Cost Effective. The Very Affordable category referred to having money in a budget to purchase the technology while the Cost Effective category projected that the technology is a reduction or savings in the budget.

In the third round, a separate survey was constructed for each member of the panel boldfacing those events which differed from the consensus opinion. On March 1, each individual was given an opportunity to change his/her response or to present an argument for disagreement. These arguments were incorporated as comments in chapter 4 allowing the reader to look beyond the calculated data. Round three also presented the results of round two to all expert panelists.

\section{Design}

Panel members were surveyed three times using a modified Delphi technique. Round one response generated a list of technology infrastructures that were presented in round two. During the second round, panelists were asked about life expectancy and affordability of listed technology infrastructures. A statistical mean and standard deviation for each time frame and each affordability factor 
were calculated. The desirable result is that consensus had been reached when the round three surveys were distributed and all panel members had an opportunity to study the results. For those areas that differed from the consensus opinion, each individual was provided an opportunity to conform to the consensus or express an opinion why his/her statement should be considered.

\section{Procedure}

Each selected member of the panel was contacted either by E-mail or by telephone during the month of December. At that time the procedure and the amount of time they would contribute were explained. Twenty-five individuals agreed to participate. More contacts were made to secure possible additions to the expert panel. Since this is a technology infrastructure study, the surveys and communication were conducted by E-mail. On January 13, 1999, E-mail notices were sent to participants thanking them for their willingness to participate and to expect the first round survey to be distributed on January 20, 1999. The surveys were distributed as a Microsoft Word attachment to E-mail. Some individuals had difficulty retrieving these attachments and an arrangement to fax the surveys was made. During the first round one of the experts was concerned about a virus that might have been attached to the file. Further investigation showed the virus was not resident on the home computer or in the file. All experts were made aware of a virus killer that they could use if there was a concern.

The first round survey asked only one question: "List as many technology infrastructures as possible that could be implemented in the construction of a new 
high school or the renovation of an existing structure. Remember to use the term infrastructure in a broad sense." The responses to this question were analyzed and common responses were reworded so that there was no duplication. A list of the responses was constructed and used on the second round instrument.

The second round used the above constructed list and asked two questions concerning each item. The queries were in the format of a Likert-like scale:

1. Consider each of the technology infrastructures listed and decide in your opinion how long these will still be viable technologies.
a) 1-5 years
b) 6-10 years
c) 11-15 years
d) 16-20 years
e) beyond 20 years

2. Consider each technology and determine in your opinion how affordable the technology is for the implementation in West Virginia schools.

1) Beyond Budget 2) Very Expensive 3) Expensive
4) Affordable
5) Very Affordable
6) Cost Effective

The statistical mean and standard deviation was calculated for each question and each item. Also calculated was the number of responses for each of the five (life expectancy) or six (affordability) categories. The mean, the standard deviation, and the distribution of responses were considered when deciding what would constitute consensus. The researcher was looking for a distribution of responses about the mean that would constitute $60 \%$ or more of the total responses. The time frames for life expectancy were broadened in some cases, which made consensus easier to achieve.

During the third round of the Delphi, the data collected and calculated from round two determined each panelist's third round survey. The participants were 
given a chance to align any response with the consensus or to support their original response.

\section{Data Analysis}

Data from the final round of the Delphi were grouped according to the life expectancy responses. Charts were then constructed that listed the Round 2 responses, Round 3 responses, education responses, and business responses. The respective means of each were also included in the table. Comments of disagreement with the group have been included after each table to give the reader an opportunity to compare the data and the dissenting opinions. From this information conclusions were drawn as to which technology infrastructures would be beneficial for school systems to consider in the construction of a high school or the renovation of an existing structure in the future. 


\section{CHAPTER 4}

\section{PRESENTATION OF THE DATA}

\section{Introduction}

The presentation of data consists of information retrieved on all three rounds of the Delphi study. The events are presented by time frame with information comparing the mean distributions of the round two and round three responses with respect to time frame and affordability of individual technology infrastructures. Each of the five time frames are presented and information concerning the time frame distribution and the affordability distribution of each technology. Round two and round three data are compared as well as data concerning the responses of educators and the responses of business people. Comments gathered in round three are also presented for each technology infrastructure.

Originally, twenty-five individuals were contacted to participate as expert panelists. Twenty-one of the original group decided to participate and were sent round one surveys on January 20, 1999. There were 21 different responses received and those were divided into the following five categories:

1. Equipment - Hubs, Palm Computer, Wireless Workpad, Laptop Computer, Electronic Whiteboard, File server.

2. Networks - Shared, Wireless, Switched.

3. Support - Help Desk, Maintenance Contract, Staff Development. 
4. Communications - CAT-5 Wire, Fiber Optic, Secure Communications Center.

5. Software - Proxy Server, Windows, Voice. Communication, Anti-Virus, LAN, LAN to WAN.

In round two, February 10, 1999, these devices were listed and the panelists were asked to rank each by time frame and affordability. Eighteen of the original twenty-one panelists responded. Of the respondents 14 were male and 4 were female, 9 were educators and 9 were business people. This was the final makeup of the expert panel for the study. On March 1, 1999, round three was sent to each of the panelists. This included their original answers as well as the consensus of the panel. Each individual was ask to review the document and agree with the consensus or support their position by March 15, 1999. Those not responding at round three were considered to be comfortable with their original answers, but not wishing to write support documentation. A breakdown of the mean time frame was as follows:

Table 4.1

Mean Life Expectancy Responses

$\begin{array}{lllll}1-5 & 6-10 & 11-15 & 16-20 & 20+\end{array}$

Years Years Years Years Years

\begin{tabular}{llllll} 
Round 2 & 0 & 5 & 9 & 6 & 1 \\
Round 3 & 0 & 5 & 9 & 6 & 1 \\
\hline
\end{tabular}


The mean life expectancies were adjusted to reflect the distribution when coming to consensus. The consensus data for round three allowed a broader time frame than the respondents used which gave some flexibility to agreement. If the respondent's time frame fell within the expanded consensus time frame then agreement was reached.

The breakdown of the mean affordability was as follows:

Table 4.2

Mean Affordability Responses

\begin{tabular}{lcccccc}
\hline & $(1)$ & $(2)$ & $(3)$ & $(4)$ & $(5)$ & $(6)$ \\
& $\mathrm{BB}$ & $\mathrm{VE}$ & $\mathrm{EX}$ & $\mathrm{AF}$ & $\mathrm{VA}$ & $\mathrm{CE}$ \\
\hline Round 2 & 0 & 0 & 7 & 7 & 7 & 0 \\
& & & & 7 & \\
Round 3 & 0 & 0 & 5 & 10 & 6 & 0 \\
\hline
\end{tabular}

These mean responses were used as the consensus data for round three and they reflect the changes submitted by the respondents.

\section{LIFE EXPECTANCY BEYOND 20 YEARS}

Only one event had a mean life expectancy of beyond twenty years. The event "staff development" was the one with a mean of beyond twenty years. Information relating to this event follows: 
Table 4.3

Time Frame Distribution

\#1 - Staff Development

\begin{tabular}{|c|c|c|c|c|c|c|}
\hline & $\begin{array}{c}(5) \\
1-5 \\
\text { Years }\end{array}$ & $\begin{array}{c}(4) \\
6-10 \\
\text { Years }\end{array}$ & $\begin{array}{c}(3) \\
11-15 \\
\text { Years }\end{array}$ & $\begin{array}{c}(2) \\
16-20 \\
\text { Years }\end{array}$ & $\begin{array}{c}(1) \\
20+ \\
\text { Years }\end{array}$ & Mean \\
\hline Round 2 & 0 & 0 & 1 & 1 & 16 & 1.17 \\
\hline Round 3 & 0 & 0 & 1 & 1 & 16 & 1.17 \\
\hline Business & 0 & 0 & 1 & 0 & 8 & 1.22 \\
\hline Education & 0 & 0 & 0 & 1 & 8 & 1.11 \\
\hline
\end{tabular}

Table 4.4

Affordability Distribution \#1-Staff Development

\begin{tabular}{lccccccc} 
& $(1)$ & $(2)$ & $(3)$ & $(4)$ & $(5)$ & $(6)$ & \\
& $\mathrm{BB}$ & $\mathrm{VE}$ & $\mathrm{EX}$ & $\mathrm{AF}$ & $\mathrm{VA}$ & $\mathrm{CE}$ & Mean \\
\hline Round 2 & 0 & 1 & 3 & 4 & 2 & 8 & 4.72 \\
Round 3 & 1 & 1 & 3 & 4 & 2 & 7 & 4.44 \\
Business & 0 & 0 & 2 & 2 & 1 & 4 & 4.78 \\
Education & 1 & 1 & 1 & 2 & 1 & 3 & 4.11 \\
\hline
\end{tabular}

One respondent commented, "There are very affordable self-paced

tools that help in this area. In addition, when you consider the added costs to a system if the staff is not trained, in my judgement, this is one of the most cost effective activities that can be undertaken." Another respondent wrote, "Just-In-Time-Learning technologies will just give training and educational software the capability of mass production which will drive the cost down." 


\section{LIFE EXPECTANCY OF 16 TO 20 YEARS}

There are six events that had a mean life expectancy of 16 to 20 years.

Those events and information about them are listed individually as they

appeared on the survey

Table 4.5

Time Frame Distribution \#2 File Server

\begin{tabular}{|c|c|c|c|c|c|c|}
\hline & $\begin{array}{c}(5) \\
1-5 \\
\text { Years }\end{array}$ & $\begin{array}{c}(4) \\
6-10 \\
\text { Years }\end{array}$ & $\begin{array}{c}(3) \\
11-15 \\
\text { Years }\end{array}$ & $\begin{array}{c}(2) \\
16-20 \\
\text { Years }\end{array}$ & $\begin{array}{c}(1) \\
20+ \\
\text { Years }\end{array}$ & Mean \\
\hline Round 2 & 1 & 2 & 5 & 4 & 6 & 2.33 \\
\hline Round 3 & 1 & 2 & 6 & 4 & 5 & 2.44 \\
\hline Business & 1 & 1 & 3 & 3 & 1 & 2.78 \\
\hline Education & 0 & 1 & 3 & 1 & 4 & 2.11 \\
\hline
\end{tabular}

Table 4.6

Affordability Distribution \#2 File Server

\begin{tabular}{lccccccc} 
& $(1)$ & $(2)$ & $(3)$ & $(4)$ & $(5)$ & $(6)$ & \\
& $\mathrm{BB}$ & $\mathrm{VE}$ & $\mathrm{EX}$ & $\mathrm{AF}$ & $\mathrm{VA}$ & $\mathrm{CE}$ & Mean \\
\hline Round 2 & 0 & 0 & 1 & 7 & 0 & 10 & 5.06 \\
Round 3 & 0 & 0 & 0 & 6 & 0 & 12 & 5.33 \\
Business & 0 & 0 & 0 & 4 & 0 & 5 & 5.11 \\
Education & 0 & 0 & 0 & 2 & 0 & 7 & 5.56 \\
\hline
\end{tabular}


Table 4.7

Time Frame Distribution \#3 Wireless Network

\begin{tabular}{|c|c|c|c|c|c|c|}
\hline & $\begin{array}{c}(5) \\
1-5 \\
\text { Years } \\
\end{array}$ & $\begin{array}{c}(4) \\
6-10 \\
\text { Years }\end{array}$ & $\begin{array}{c}(3) \\
11-15 \\
\text { Years }\end{array}$ & $\begin{array}{c}(2) \\
16-20 \\
\text { Years }\end{array}$ & $\begin{array}{c}(1) \\
20+ \\
\text { Years }\end{array}$ & Mean \\
\hline Round 2 & 1 & 1 & 4 & 5 & 7 & 2.11 \\
\hline Round 3 & 1 & 1 & 4 & 5 & 7 & 2.11 \\
\hline Business & 0 & 1 & 3 & 2 & 3 & 2.22 \\
\hline Education & 1 & 0 & 1 & 3 & 4 & 2.00 \\
\hline
\end{tabular}

Table 4.8

Affordability Distribution \#3 Wireless Network

\begin{tabular}{lccccccc} 
& $(1)$ & $(2)$ & $(3)$ & $(4)$ & $(5)$ & $(6)$ & \\
& BB & VE & EX & AF & VA & CE & Mean \\
\hline Round 2 & 4 & 2 & 9 & 2 & 1 & 0 & 2.67 \\
Round 3 & 3 & 2 & 8 & 4 & 1 & 0 & 2.89 \\
Business & 2 & 1 & 3 & 2 & 1 & 0 & 2.89 \\
Education & 1 & 1 & 5 & 2 & 0 & 0 & 2.89 \\
\hline
\end{tabular}

The architect member of the panel summed up wireless networks by saying, "This seems to be a big difference of opinion for costs but I still feel that it is over most of my budgets and most clients don't feel comfortable with this system." 
Table 4.9

Time Frame Distribution \#4 Help Desk

\begin{tabular}{lcccccc} 
& $(5)$ & $(4)$ & $(3)$ & $(2)$ & $(1)$ & \\
& $\begin{array}{c}1-5 \\
\text { Years }\end{array}$ & $\begin{array}{c}\text { Years } \\
\end{array}$ & $\begin{array}{c}11-15 \\
\text { Years }\end{array}$ & $\begin{array}{c}16-20 \\
\text { Years }\end{array}$ & $\begin{array}{c}\text { Years } \\
\text { Years }\end{array}$ & Mean \\
\hline Round 2 & 1 & 1 & 2 & 3 & 11 & 1.78 \\
Round 3 & 1 & 1 & 2 & 3 & 11 & 1.78 \\
Business & 1 & 0 & 2 & 1 & 5 & 2.00 \\
Education & 0 & 1 & 0 & 2 & 6 & 1.56 \\
\hline
\end{tabular}

Table 4.10

Affordability Distribution \#4 Help Desk

\begin{tabular}{lccccccc} 
& $(1)$ & $(2)$ & $(3)$ & $(4)$ & $(5)$ & $(6)$ & \\
& BB & VE & EX & AF & VA & CE & Mean \\
\hline Round 2 & 0 & 2 & 8 & 2 & 2 & 4 & 3.89 \\
Round 3 & 0 & 2 & 9 & 1 & 2 & 4 & 3.83 \\
Business & 0 & 1 & 4 & 1 & 1 & 2 & 3.89 \\
Education & 0 & 1 & 5 & 0 & 1 & 2 & 3.78 \\
\hline
\end{tabular}

Table 4.11

Time Frame Distribution \#5 Maintenance Contract

\begin{tabular}{|c|c|c|c|c|c|c|}
\hline & $\begin{array}{c}(5) \\
1-5 \\
\text { Years } \\
\end{array}$ & $\begin{array}{c}(4) \\
6-10 \\
\text { Years } \\
\end{array}$ & $\begin{array}{c}(3) \\
11-15 \\
\text { Years }\end{array}$ & $\begin{array}{c}(2) \\
16-20 \\
\text { Years }\end{array}$ & $\begin{array}{c}(1) \\
20+ \\
\text { Years }\end{array}$ & Mean \\
\hline Round 2 & 0 & 0 & 5 & 1 & 12 & 1.61 \\
\hline Round 3 & 0 & 0 & 4 & 1 & 13 & 1.50 \\
\hline Business & 0 & 0 & 4 & 1 & 4 & 2.00 \\
\hline Education & 0 & 0 & 0 & 0 & 9 & 1.00 \\
\hline
\end{tabular}


Table 4.12

Affordability Distribution \#5 Maintenance Contract

\begin{tabular}{lccccccc} 
& $(1)$ & $(2)$ & $(3)$ & $(4)$ & $(5)$ & $(6)$ & \\
& $\mathrm{BB}$ & $\mathrm{VE}$ & $\mathrm{EX}$ & $\mathrm{AF}$ & $\mathrm{VA}$ & $\mathrm{CE}$ & Mean \\
\hline Round 2 & 0 & 4 & 7 & 5 & 1 & 1 & 3.33 \\
Round 3 & 0 & 4 & 6 & 4 & 1 & 3 & 3.61 \\
Business & 0 & 3 & 3 & 3 & 0 & 0 & 3.00 \\
Education & 0 & 1 & 3 & 1 & 1 & 3 & 4.22 \\
\hline
\end{tabular}

Two comments on maintenance contracts were submitted. "It is only cost effective if it is GOOD HELP and the organization does not have well qualified personnel on staff." "My last client spent 150k in one year for a local company to service his school system. This was in addition to his technology department of 5 persons. The next year he hired a network person to run this department at a lot less than 150k."

Table 4.13

Time Frame Distribution

\#6 Fiber Optic

\begin{tabular}{|c|c|c|c|c|c|c|}
\hline & $\begin{array}{c}(5) \\
1-5 \\
\text { Years } \\
\end{array}$ & $\begin{array}{c}(4) \\
6-10 \\
\text { Years }\end{array}$ & $\begin{array}{c}(3) \\
11-15 \\
\text { Years }\end{array}$ & $\begin{array}{c}(2) \\
16-20 \\
\text { Years }\end{array}$ & $\begin{array}{c}(1) \\
20+ \\
\text { Years }\end{array}$ & Mean \\
\hline Round 2 & 0 & 5 & 4 & 2 & 7 & 2.39 \\
\hline Round 3 & 0 & 5 & 4 & 2 & 7 & 2.39 \\
\hline Business & 0 & 2 & 2 & 2 & 3 & 2.33 \\
\hline Education & 0 & 3 & 2 & 0 & 4 & 2.44 \\
\hline
\end{tabular}


Table 4.14

Affordability Distribution \#6 Fiber Optic

\begin{tabular}{lccccccc} 
& $(1)$ & $(2)$ & $(3)$ & $(4)$ & $(5)$ & $(6)$ & \\
& $\mathrm{BB}$ & $\mathrm{VE}$ & $\mathrm{EX}$ & $\mathrm{AF}$ & $\mathrm{VA}$ & $\mathrm{CE}$ & Mean \\
\hline Round 2 & 0 & 2 & 5 & 6 & 3 & 2 & 3.89 \\
Round 3 & 0 & 2 & 6 & 5 & 3 & 2 & 3.83 \\
Business & 0 & 0 & 3 & 3 & 1 & 2 & 4.22 \\
Education & 0 & 2 & 3 & 2 & 2 & 0 & 3.44 \\
\hline
\end{tabular}

Many ideas about fiber optic cable were expressed. "The amount of this used in most systems makes this affordable." "With more users we need the fiber, especially for backbone. The greater the number of users the more traffic, the greater the need." "Using the right design fiber optic cable is no more expensive than CAT-5 copper because of the amount of each needed and the use to which it can be put." "The key to the 'seamless ubiquitous computing environment'. Cost reducations are in the Teraflop and Petaflop technologies and the 100GB communications environment."

Table 4.15

Time Frame Distribution \#7 Anti-Virus Software

$\begin{array}{lllll}(5) & (4) \quad(3) \quad(2) \quad(1)\end{array}$

1-5 6-10 11-15 16-20 20+ Mean

Years Years Years Years Years

\begin{tabular}{lcccccc}
\hline Round 2 & 1 & 3 & 4 & 1 & 9 & 2.22 \\
Round 3 & 1 & 3 & 4 & 1 & 0 & 2.22 \\
Business & 1 & 2 & 3 & 1 & 2 & 2.89 \\
Education & 0 & 1 & 1 & 0 & 7 & 1.56 \\
\hline
\end{tabular}


Table 4.16

Affordability Distribution \#7 Anti-Virus Software

\begin{tabular}{lccccccc} 
& $(1)$ & $(2)$ & $(3)$ & $(4)$ & $(5)$ & $(6)$ & \\
& BB & VE & EX & AF & VA & CE & Mean \\
\hline Round 2 & 0 & 0 & 0 & 4 & 5 & 9 & 5.28 \\
Round 3 & 0 & 0 & 0 & 5 & 5 & 8 & 5.17 \\
Business & 0 & 0 & 0 & 1 & 5 & 3 & 5.22 \\
Education & 0 & 0 & 0 & 4 & 0 & 5 & 5.11 \\
\hline
\end{tabular}

Two of the experts expressed the same sentiment about anti-virus

software. "Since this comes bundled with many systems, and since it runs about $\$ 50$ a pop if you have to buy it, I consider that pretty cost effective, especially since you can get a better price if you buy multiple copies."

\section{LIFE EXPECTANCY OF 11 TO 15 YEARS}

There are nine events that have a life expectancy of 11 to 15 years. Those events and information about them in the order they appeared on the survey follows: 
Table 4.17

Time Frame Distribution
\#8 Palm Computers

$\begin{array}{llll}(5) & (4) \quad(3) \quad(2) \quad(1)\end{array}$

1-5 6-10 11-15 16-20 20+ Mean

Years Years Years Years Years

\begin{tabular}{lllllll}
\hline Round 2 & 4 & 3 & 7 & 1 & 3 & 3.22 \\
Round 3 & 4 & 3 & 8 & 1 & 2 & 3.33 \\
Business & 2 & 2 & 3 & 1 & 1 & 3.33 \\
Education & 2 & 1 & 5 & 0 & 1 & 3.33 \\
\hline
\end{tabular}

Table 4.18

Affordability Distribution \#8 Palm Computers

\begin{tabular}{lccccccc} 
& $(1)$ & $(2)$ & $(3)$ & $(4)$ & $(5)$ & $(6)$ & \\
& BB & VE & EX & AF & VA & CE & Mean \\
\hline Round 2 & 4 & 4 & 7 & 3 & 0 & 0 & 2.50 \\
Round 3 & 3 & 4 & 8 & 3 & 0 & 0 & 2.61 \\
Business & 1 & 3 & 2 & 3 & 0 & 0 & 2.78 \\
Education & 2 & 1 & 6 & 0 & 0 & 0 & 2.44 \\
\hline
\end{tabular}

Palm computers were characterized by the following quotes. "The palm computer will go the distance however I think that it will keep going through big changes and the price will continue to drop from very expensive to low end expensive to the average owner." "If your [sic] talking about one (palm computer), I would agree. If you're talking about making these available to teachers and/or students, I think $\$ 400+$ is too much money." 
Table 4.19

Time Frame Distribution

\#9 Wireless Workpad

\begin{tabular}{|c|c|c|c|c|c|c|}
\hline & $\begin{array}{c}(5) \\
1-5 \\
\text { Years }\end{array}$ & $\begin{array}{c}(4) \\
6-10 \\
\text { Years }\end{array}$ & $\begin{array}{c}(3) \\
11-15 \\
\text { Years }\end{array}$ & $\begin{array}{c}(2) \\
16-20 \\
\text { Years }\end{array}$ & $\begin{array}{c}(1) \\
20+ \\
\text { Years }\end{array}$ & Mean \\
\hline Round 2 & 4 & 2 & 4 & 4 & 3 & 3.00 \\
\hline Round 3 & 4 & 2 & 5 & 4 & 2 & 3.12 \\
\hline Business & 3 & 1 & 1 & 2 & 2 & 3.11 \\
\hline Education & 1 & 1 & 4 & 2 & 0 & 3.13 \\
\hline
\end{tabular}

Table 4.20

Affordability Distribution \#9 Wireless Workpad

\begin{tabular}{lccccccc} 
& $(1)$ & $(2)$ & $(3)$ & $(4)$ & $(5)$ & $(6)$ & \\
& BB & VE & EX & AF & VA & CE & Mean \\
\hline Round 2 & 2 & 5 & 8 & 2 & 0 & 0 & 2.59 \\
Round 3 & 2 & 4 & 9 & 2 & 0 & 0 & 2.65 \\
Business & 1 & 3 & 3 & 2 & 0 & 0 & 2.67 \\
Education & 1 & 1 & 6 & 0 & 0 & 0 & 2.63 \\
\hline
\end{tabular}

Table 4.21

Time Frame Distribution \#10 Laptop Computers

\begin{tabular}{|c|c|c|c|c|c|c|}
\hline & $\begin{array}{c}(5) \\
1-5 \\
\text { Years }\end{array}$ & $\begin{array}{c}(4) \\
6-10 \\
\text { Years }\end{array}$ & $\begin{array}{c}(3) \\
11-15 \\
\text { Years }\end{array}$ & $\begin{array}{c}(2) \\
16-20 \\
\text { Years }\end{array}$ & $\begin{array}{c}(1) \\
20+ \\
\text { Years }\end{array}$ & Mean \\
\hline Round 2 & 1 & 5 & 3 & 2 & 7 & 2.50 \\
\hline Round 3 & 1 & 5 & 4 & 2 & 6 & 2.61 \\
\hline Business & 0 & 3 & 2 & 1 & 3 & 2.56 \\
\hline Education & 1 & 2 & 2 & 1 & 3 & 2.67 \\
\hline
\end{tabular}


Table 4.22

Affordability Distribution \#10 Laptop Computers

\begin{tabular}{lccccccc} 
& $(1)$ & $(2)$ & $(3)$ & $(4)$ & $(5)$ & $(6)$ & \\
& BB & VE & EX & AF & VA & CE & Mean \\
\hline Round 2 & 0 & 5 & 7 & 6 & 0 & 0 & 3.06 \\
Round 3 & 0 & 6 & 6 & 6 & 0 & 0 & 3.00 \\
Business & 0 & 3 & 3 & 3 & 0 & 0 & 3.00 \\
Education & 0 & 3 & 3 & 3 & 0 & 0 & 3.00 \\
\hline
\end{tabular}

Some of the expert panelists commented that laptop computers are not quite so expensive if you are considering individual pieces of equipment. When talking about classrooms filled with laptop computers however, this technology infrastructure was thought to be very expensive.

Table 4.23 Time Frame Distribution \#11 Shared Networks

\begin{tabular}{lcccccc} 
& $(5)$ & $(4)$ & $(3)$ & $(2)$ & $(1)$ & \\
& $1-5$ & $6-10$ & $11-15$ & $16-20$ & $20+$ & Mean \\
& Years & Years & Years & Years & Years & \\
\hline Round 2 & 2 & 3 & 5 & 3 & 4 & 2.76 \\
Round 3 & 2 & 1 & 7 & 3 & 4 & 2.65 \\
Business & 2 & 1 & 3 & 1 & 1 & 3.25 \\
Education & 0 & 0 & 4 & 2 & 3 & 2.11 \\
\hline
\end{tabular}


Table 4.24

Affordability Distribution \#11 Shared Networks

\begin{tabular}{lccccccc} 
& $(1)$ & $(2)$ & $(3)$ & $(4)$ & $(5)$ & $(6)$ & \\
& $\mathrm{BB}$ & $\mathrm{VE}$ & $\mathrm{EX}$ & $\mathrm{AF}$ & $\mathrm{VA}$ & $\mathrm{CE}$ & Mean \\
\hline Round 2 & 0 & 0 & 1 & 6 & 3 & 8 & 5.00 \\
Round 3 & 0 & 2 & 1 & 4 & 3 & 8 & 4.78 \\
Business & 0 & 0 & 1 & 2 & 2 & 4 & 5.00 \\
Education & 0 & 2 & 0 & 2 & 1 & 4 & 4.56 \\
\hline
\end{tabular}

One individual had this thought about shared networks. "If optical networks are as seamless as visioned in 10 to 20 years the monopolistic costs of carriers will be greatly reduced. In my opinion this will be the key to educational infrastructures of the future."

\begin{tabular}{|c|c|c|c|c|c|c|}
\hline \multicolumn{3}{|c|}{ Time Frame Distribution } & \multicolumn{3}{|c|}{ \#12 Switched Networks } & \\
\hline & $\begin{array}{c}(5) \\
1-5 \\
\text { Years } \\
\end{array}$ & $\begin{array}{c}(4) \\
6-10 \\
\text { Years }\end{array}$ & $\begin{array}{c}(3) \\
11-15 \\
\text { Years }\end{array}$ & $\begin{array}{c}(2) \\
16-20 \\
\text { Years }\end{array}$ & $\begin{array}{c}(1) \\
20+ \\
\text { Years }\end{array}$ & Mean \\
\hline Round 2 & 3 & 7 & 4 & 1 & 3 & 3.33 \\
\hline Round 3 & 3 & 7 & 4 & 1 & 3 & 3.33 \\
\hline Business & 1 & 5 & 3 & 0 & 0 & 3.78 \\
\hline Education & 2 & 2 & 1 & 1 & 3 & 2.89 \\
\hline
\end{tabular}

Table 4.26

Affordability Distribution \#12 Switched Networks

\begin{tabular}{lccccccc} 
& $(1)$ & $(2)$ & $(3)$ & $(4)$ & $(5)$ & $(6)$ & \\
& $\mathrm{BB}$ & $\mathrm{VE}$ & $\mathrm{EX}$ & $\mathrm{AF}$ & $\mathrm{VA}$ & $\mathrm{CE}$ & Mean \\
\hline Round 2 & 0 & 0 & 5 & 9 & 1 & 2 & 4.00 \\
Round 3 & 0 & 0 & 7 & 8 & 1 & 2 & 4.00 \\
Business & 0 & 0 & 4 & 3 & 1 & 1 & 3.89 \\
Education & 0 & 0 & 3 & 5 & 0 & 1 & 3.89 \\
\hline
\end{tabular}


Regarding switched networks, the panel had the following to say.

"This is today's IP and ATM environment and prices are dropping." "I don't know what's going to replace switched networks in the very near future. Therefore, my crystal ball suggests they will be around for a while."

Table 4.27

Time Frame Distribution

\begin{tabular}{lcccccc} 
& $(5)$ & $(4)$ & $(3)$ & $(2)$ & $(1)$ & \\
& $1-5$ & $6-10$ & $11-15$ & $16-20$ & $20+$ & Mean \\
& Years & Years & Years & Years & Years & \\
\hline Round 2 & 1 & 5 & 3 & 3 & 6 & 2.56 \\
Round 3 & 1 & 5 & 3 & 3 & 6 & 2.56 \\
Business & 0 & 4 & 0 & 3 & 2 & 2.67 \\
Education & 1 & 1 & 3 & 0 & 4 & 2.44 \\
\hline
\end{tabular}

Table 4.28

Affordability Distribution \#13 Voice Communication Software

\begin{tabular}{lccccccc} 
& $(1)$ & $(2)$ & $(3)$ & $(4)$ & $(5)$ & $(6)$ & \\
& $\mathrm{BB}$ & $\mathrm{VE}$ & $\mathrm{EX}$ & $\mathrm{AF}$ & $\mathrm{VA}$ & $\mathrm{CE}$ & Mean \\
\hline Round 2 & 1 & 2 & 4 & 8 & 2 & 1 & 3.61 \\
Round 3 & 0 & 2 & 3 & 7 & 2 & 4 & 4.17 \\
Business & 0 & 2 & 0 & 5 & 1 & 1 & 3.89 \\
Education & 0 & 0 & 3 & 2 & 1 & 3 & 4.44 \\
\hline
\end{tabular}


Table 4.29

Time Frame Distribution \#14 Local Area Network Software

\begin{tabular}{|c|c|c|c|c|c|c|}
\hline & $\begin{array}{c}(5) \\
1-5 \\
\text { Years } \\
\end{array}$ & $\begin{array}{c}(4) \\
6-10 \\
\text { Years } \\
\end{array}$ & $\begin{array}{c}(3) \\
11-15 \\
\text { Years }\end{array}$ & $\begin{array}{c}(2) \\
16-20 \\
\text { Years } \\
\end{array}$ & $\begin{array}{c}(1) \\
20+ \\
\text { Years } \\
\end{array}$ & Mean \\
\hline Round 2 & 1 & 4 & 7 & 1 & 5 & 2.72 \\
\hline Round 3 & 1 & 4 & 8 & 1 & 4 & 2.83 \\
\hline Business & 1 & 4 & 2 & 0 & 2 & 3.22 \\
\hline Education & 0 & 0 & 6 & 1 & 2 & 2.44 \\
\hline
\end{tabular}

Table 4.30

Affordability Distribution \#14 Local Area Network Software

\begin{tabular}{lccccccc} 
& $(1)$ & $(2)$ & $(3)$ & $(4)$ & $(5)$ & $(6)$ & \\
& $\mathrm{BB}$ & $\mathrm{VE}$ & $\mathrm{EX}$ & $\mathrm{AF}$ & $\mathrm{VA}$ & $\mathrm{CE}$ & Mean \\
\hline Round 2 & 0 & 1 & 2 & 7 & 5 & 3 & 4.39 \\
Round 3 & 0 & 1 & 1 & 9 & 5 & 2 & 4.33 \\
Business & 0 & 0 & 1 & 4 & 4 & 0 & 4.33 \\
Education & 0 & 1 & 0 & 5 & 1 & 2 & 4.33 \\
\hline
\end{tabular}

Table 4.31

Time Frame Distribution

\#15 LAN to WAN Software

\begin{tabular}{lcccccc} 
& $(5)$ & $(4)$ & $(3)$ & $(2)$ & $(1)$ & \\
& $1-5$ & $6-10$ & $11-15$ & $16-20$ & $20+$ & Mean \\
& Years & Years & Years & Years & Years & \\
\hline Round 2 & 0 & 4 & 7 & 3 & 4 & 2.61 \\
Round 3 & 0 & 4 & 7 & 3 & 4 & 2.61 \\
Business & 0 & 4 & 3 & 1 & 1 & 3.11 \\
Education & 0 & 0 & 4 & 2 & 3 & 2.11 \\
\hline
\end{tabular}


Table 4.32

Affordability Distribution \#15 LAN to WAN Software

\begin{tabular}{lccccccc} 
& $(1)$ & $(2)$ & $(3)$ & $(4)$ & $(5)$ & $(6)$ & \\
& BB & VE & EX & AF & VA & CE & Mean \\
\hline Round 2 & 0 & 0 & 4 & 7 & 5 & 2 & 4.28 \\
Round 3 & 0 & 3 & 3 & 6 & 4 & 2 & 3.94 \\
Business & 0 & 0 & 2 & 4 & 3 & 0 & 4.11 \\
Education & 0 & 3 & 1 & 2 & 1 & 2 & 3.78 \\
\hline
\end{tabular}

Table 4.33

Time Frame Distribution

\#16 Secure Comm. Center

\begin{tabular}{lcccccc} 
& $(5)$ & $(4)$ & $(3)$ & $(2)$ & $(1)$ & \\
& $\begin{array}{c}1-5 \\
\text { Years }\end{array}$ & $\begin{array}{c}\text { Years } \\
\text { Year }\end{array}$ & $\begin{array}{c}11-15 \\
\text { Years }\end{array}$ & $\begin{array}{c}16-20 \\
\text { Years }\end{array}$ & $\begin{array}{c}\text { Years } \\
\text { Years }\end{array}$ & Mean \\
\hline Round 2 & 0 & 6 & 3 & 4 & 3 & 2.75 \\
Round 3 & 0 & 8 & 3 & 4 & 2 & 3.00 \\
Business & 0 & 3 & 2 & 1 & 2 & 2.75 \\
Education & 0 & 5 & 1 & 3 & 0 & 3.22 \\
\hline
\end{tabular}

Table 4.34

Affordability Distribution \#16 Secure Communications Center

\begin{tabular}{lccccccc} 
& $(1)$ & $(2)$ & $(3)$ & $(4)$ & $(5)$ & $(6)$ & \\
& BB & VE & EX & AF & VA & CE & Mean \\
\hline Round 2 & 0 & 5 & 8 & 2 & 1 & 1 & 3.12 \\
Round 3 & 0 & 5 & 7 & 4 & 1 & 1 & 3.22 \\
Business & 0 & 2 & 4 & 2 & 1 & 0 & 3.22 \\
Education & 0 & 3 & 3 & 2 & 0 & 1 & 3.22 \\
\hline
\end{tabular}


One comment was expressed on secure communication centers. "I think the extra fire walls, possibly including a separate server, and the associated switches and software makes this very expensive." Some respondents were unsure what was involved with this infrastructure.

\section{LIFE EXPECTANCY OF 6-10 YEARS}

There are five events that have a life expectancy of 6-10 years. These events and information about them are listed in the order they appeared on the survey follows:

\begin{tabular}{lcccccc}
$\begin{array}{l}\text { Table 4.35 } \\
\text { Time Frame Distribution }\end{array}$ & \multicolumn{7}{c}{ \#17 Network Hubs } \\
\hline & $\begin{array}{c}(5) \\
1-5\end{array}$ & $\begin{array}{c}(4) \\
6-10\end{array}$ & $\begin{array}{c}(3) \\
11-15\end{array}$ & $\begin{array}{c}16-20 \\
16-20\end{array}$ & $\begin{array}{c}(1) \\
20+\end{array}$ & Mean \\
& Years & Years & Years & Years & Years & \\
\hline Round 2 & 4 & 9 & 3 & 1 & 1 & 3.78 \\
Round 3 & 5 & 8 & 3 & 1 & 1 & 3.83 \\
Business & 2 & 5 & 1 & 0 & 1 & 3.78 \\
Education & 3 & 3 & 2 & 1 & 0 & 3.89 \\
\hline
\end{tabular}


Table 4.36

Affordability Distribution \#17 Network Hubs

\begin{tabular}{lccccccc} 
& $(1)$ & $(2)$ & $(3)$ & $(4)$ & $(5)$ & $(6)$ & \\
& $\mathrm{BB}$ & $\mathrm{VE}$ & $\mathrm{EX}$ & $\mathrm{AF}$ & $\mathrm{VA}$ & $\mathrm{CE}$ & Mean \\
\hline Round 2 & 0 & 1 & 3 & 6 & 2 & 6 & 4.50 \\
Round 3 & 0 & 3 & 2 & 6 & 2 & 5 & 4.22 \\
Business & 0 & 2 & 0 & 4 & 1 & 2 & 4.11 \\
Education & 0 & 1 & 2 & 2 & 1 & 3 & 4.33 \\
\hline
\end{tabular}

Information was received from several panelists concerning network hubs. "This question is the leading indicator for the follow up on technology parameters of your study. Research is now being conducted to determine at what point will the total 'optical network' be available.

Estimated time frames and technologies you identified in questions 1 and 2 will be directly affected by this answer. The projected date is 2010 based on the Presidents Information Technology Advisory Council Report dated 2/24/99." "Perhaps the other respondents know something I don't, but I haven't seen any predictions or suggestions that there is something in the works to replace a hub." "I think that the network hub will go 10 years but after 5 years it will more than likely be upgraded or modified in some way." 
Table 4.37

Time Frame Distribution \#18 Electronic Whiteboards

\begin{tabular}{lcccccc} 
& $(5)$ & $(4)$ & $(3)$ & $(2)$ & $(1)$ & \\
& $\begin{array}{c}1-5 \\
\text { Years }\end{array}$ & $\begin{array}{c}\text { Years } \\
\text { Years }\end{array}$ & $\begin{array}{c}11-15 \\
\text { Years }\end{array}$ & $\begin{array}{c}\text { Years } \\
\text { Years }\end{array}$ & $\begin{array}{c}20+ \\
\text { Years }\end{array}$ & Mean \\
\hline Round 2 & 4 & 6 & 6 & 1 & 1 & 3.61 \\
Round 3 & 4 & 6 & 6 & 1 & 1 & 3.61 \\
Business & 1 & 3 & 4 & 1 & 0 & 3.44 \\
Education & 3 & 3 & 2 & 0 & 1 & 3.78 \\
\hline
\end{tabular}

Table 4.38

Affordability Distribution \#18 Electronic Whiteboards

\begin{tabular}{lccccccc} 
& $(1)$ & $(2)$ & $(3)$ & $(4)$ & $(5)$ & $(6)$ & \\
& BB & VE & EX & AF & VA & CE & Mean \\
\hline Round 2 & 2 & 1 & 7 & 5 & 3 & 0 & 3.33 \\
Round 3 & 1 & 1 & 7 & 4 & 3 & 2 & 3.72 \\
Business & 0 & 1 & 3 & 3 & 1 & 1 & 3.78 \\
Education & 1 & 0 & 4 & 1 & 2 & 1 & 3.67 \\
\hline
\end{tabular}

Two opinions were expressed in regards to electronic whiteboards.

"When you consider the fact that all the features of a white board can be obtained through software and other much cheaper technology, I still feel they justify as 'Expensive'." "I feel that the value is not equal to the cost. Other technologies will soon overcome this item." 
Table 4.39

Time Frame Distribution \#19 CAT-5 Wire

\begin{tabular}{|c|c|c|c|c|c|c|}
\hline & $\begin{array}{c}(5) \\
1-5 \\
\text { Years } \\
\end{array}$ & $\begin{array}{c}(4) \\
6-10 \\
\text { Years }\end{array}$ & $\begin{array}{c}(3) \\
11-15 \\
\text { Years }\end{array}$ & $\begin{array}{c}(2) \\
16-20 \\
\text { Years }\end{array}$ & $\begin{array}{c}(1) \\
20+ \\
\text { Years }\end{array}$ & Mean \\
\hline Round 2 & 4 & 9 & 4 & 0 & 0 & 4.00 \\
\hline Round 3 & 4 & 9 & 4 & 0 & 0 & 4.00 \\
\hline Business & 3 & 3 & 3 & 0 & 0 & 4.00 \\
\hline Education & 1 & 6 & 1 & 0 & 0 & 4.00 \\
\hline
\end{tabular}

Table 4.40

Affordability Distribution \#19 CAT-5 Wire

\begin{tabular}{lccccccc} 
& $(1)$ & $(2)$ & $(3)$ & $(4)$ & $(5)$ & $(6)$ & \\
& $\mathrm{BB}$ & $\mathrm{VE}$ & $\mathrm{EX}$ & $\mathrm{AF}$ & $\mathrm{VA}$ & $\mathrm{CE}$ & Mean \\
\hline Round 2 & 0 & 0 & 1 & 4 & 9 & 3 & 4.82 \\
Round 3 & 0 & 0 & 1 & 6 & 7 & 3 & 4.71 \\
Business & 0 & 0 & 0 & 2 & 5 & 1 & 4.88 \\
Education & 0 & 0 & 1 & 4 & 2 & 2 & 4.56 \\
\hline
\end{tabular}

Table 4.41

Time Frame Distribution

\#20 Proxy Server Software

\begin{tabular}{lcccccc} 
& $(5)$ & $(4)$ & $(3)$ & $(2)$ & $(1)$ & \\
& $1-5$ & $6-10$ & $11-15$ & $16-20$ & $20+$ & Mean \\
& Years & Years & Years & Years & Years & \\
\hline Round 2 & 2 & 12 & 2 & 1 & 1 & 3.72 \\
Round 3 & 2 & 13 & 1 & 1 & 1 & 3.78 \\
Business & 0 & 9 & 0 & 0 & 0 & 4.00 \\
Education & 2 & 4 & 1 & 1 & 1 & 3.56 \\
\hline
\end{tabular}


Table 4.42

Affordability Distribution \#20 Proxy Server Software

\begin{tabular}{lccccccc} 
& $(1)$ & $(2)$ & $(3)$ & $(4)$ & $(5)$ & $(6)$ & \\
& BB & VE & EX & AF & VA & CE & Mean \\
\hline Round 2 & 0 & 1 & 4 & 8 & 4 & 1 & 4.00 \\
Round 3 & 0 & 0 & 3 & 7 & 3 & 5 & 4.56 \\
Business & 0 & 0 & 2 & 4 & 2 & 1 & 4.22 \\
Education & 0 & 0 & 1 & 3 & 1 & 4 & 4.89
\end{tabular}

Table 4.43

Time Frame Distribution \#21 Windows Software

\begin{tabular}{lcccccc} 
& $(5)$ & $(4)$ & $(3)$ & $(2)$ & $(1)$ & \\
& $1-5$ & $6-10$ & $11-15$ & $16-20$ & $20+$ & Mean \\
& Years & Years & Years & Years & Years & \\
\hline Round 2 & 4 & 7 & 5 & 0 & 2 & 3.61 \\
Round 3 & 4 & 8 & 4 & 0 & 2 & 3.67 \\
Business & 2 & 4 & 3 & 0 & 0 & 3.89 \\
Education & 2 & 4 & 1 & 0 & 2 & 3.44 \\
\hline
\end{tabular}

Table 4.44

Affordability Distribution \#21 Windows Software

\begin{tabular}{lccccccc} 
& $(1)$ & $(2)$ & $(3)$ & $(4)$ & $(5)$ & $(6)$ & \\
& BB & VE & EX & AF & VA & CE & Mean \\
\hline Round 2 & 0 & 0 & 1 & 6 & 2 & 6 & 4.89 \\
Round 3 & 0 & 0 & 1 & 8 & 5 & 4 & 4.67 \\
Business & 0 & 0 & 1 & 4 & 3 & 1 & 4.44 \\
Education & 0 & 0 & 0 & 4 & 2 & 3 & 4.89 \\
\hline
\end{tabular}


A timely comment about Windows software was offered. "They could be right on the time frame, if they're talking about the current configuration of Windows or if Microsoft looses the suit. I'm betting they won't. Therefore, since their market penetration is so great, I think Windows (or it's next version NT Workstation Professional which MS has already announced will replace Windows 98, and subsequent iterations,) will be around for a long time. Since even low end desktops now come with Windows bundled into the workstation, I stick by my guns that it is Cost Effective." 


\title{
CHAPTER 5
}

\section{SCENARIO, SUMMARY, CONCLUSIONS AND RECOMMENDATIONS}

\author{
Scenario \\ The initial panel of experts for this study consisted of 25 \\ individuals who were selected because their employment positions \\ require them to have close contact with technology infrastructures. \\ The following table illustrates the diversity of the panel. All twenty- \\ five contributed something to the study although only eighteen of them \\ participated in all three rounds.
}

Table 5.1

Occupations of Expert Panel

\begin{tabular}{|c|c|c|}
\hline Occupation & $\begin{array}{l}\text { Original } \\
\text { Panel }\end{array}$ & $\begin{array}{l}\text { Final } \\
\text { Panel }\end{array}$ \\
\hline Higher Education & 5 & 2 \\
\hline W.V. Dept. of Ed. & 5 & 3 \\
\hline Private Corp. & 8 & 7 \\
\hline Foreign Corp. & 1 & 1 \\
\hline Gov's Tech Office & 2 & 1 \\
\hline Local Schools & 3 & 3 \\
\hline Architects & 1 & 1 \\
\hline
\end{tabular}

Data received from the expert panel provided twenty-one different technology infrastructures that were divided into the following five categories: 
6. Equipment - Hubs, Palm Computer, Wireless Workpad, Laptop Computer, Electronic Whiteboard, File server.

7. Networks - Shared, Wireless, Switched.

8. Support - Help Desk, Maintenance Contract, Staff Development.

9. Communications - CAT-5 Wire, Fiber Optic, Secure Communications Center.

10. Software - Proxy Server, Windows, Voice. Communication, Antivirus, LAN, LAN to WAN.

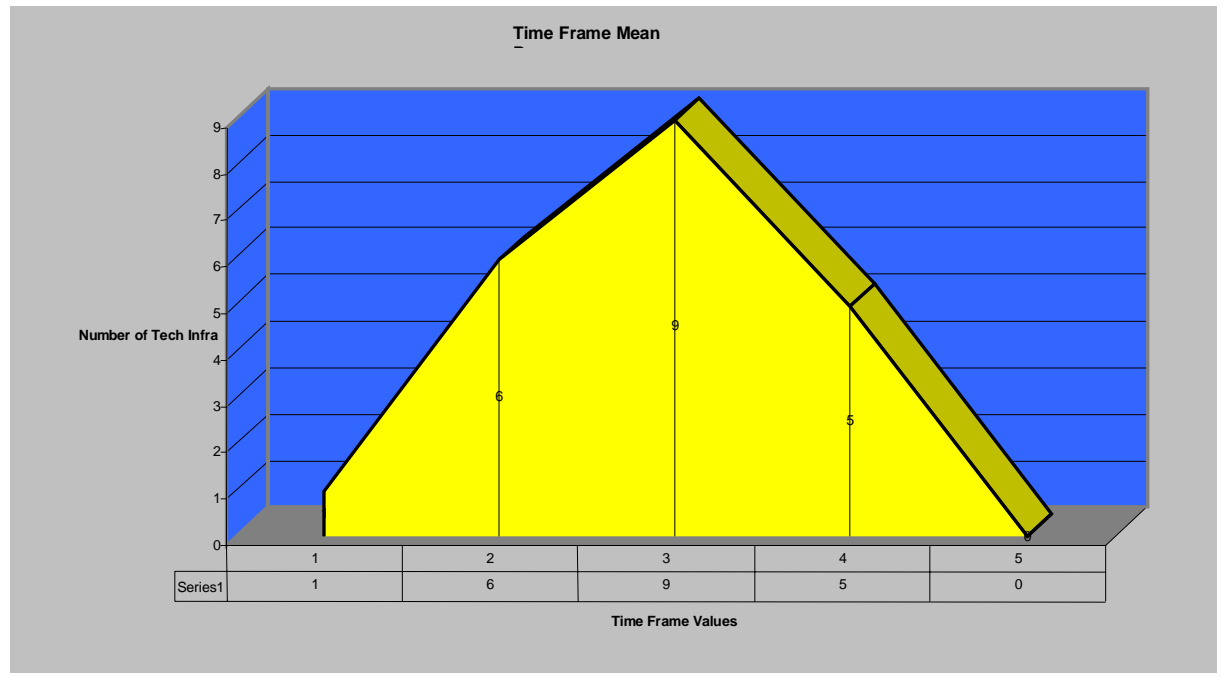

Fig. 5.1. TIME FRAME GRAPH

The presentation of data in chapter 4 was by time frame and the first time frame, 1 to 5 years, was not selected for any of the infrastructures. This would appear to indicate that all of the panelists believed that the twenty-one infrastructures selected would be available and useful for a minimum of 5 years. The responses also reported that most of the infrastructures (9) would be available and useful for 11 - 15 years. Time frame 6-10 years had 5, time frame 16-20 years had 6, and time frame beyond 20 years had 1 listed. Assigning a value of 1 to the category beyond 20 years, 2 to the category 16- 
20 years, 3 to the category $11-15$ years, 4 to the category 6-10 years, and 5 to the category 0-5 years the distribution becomes a normal distribution with a mean of 2.7 and a standard deviation of 1.00 which for this study's purpose puts the mean at the time frame 11-16 years and a standard deviation of one time frame.

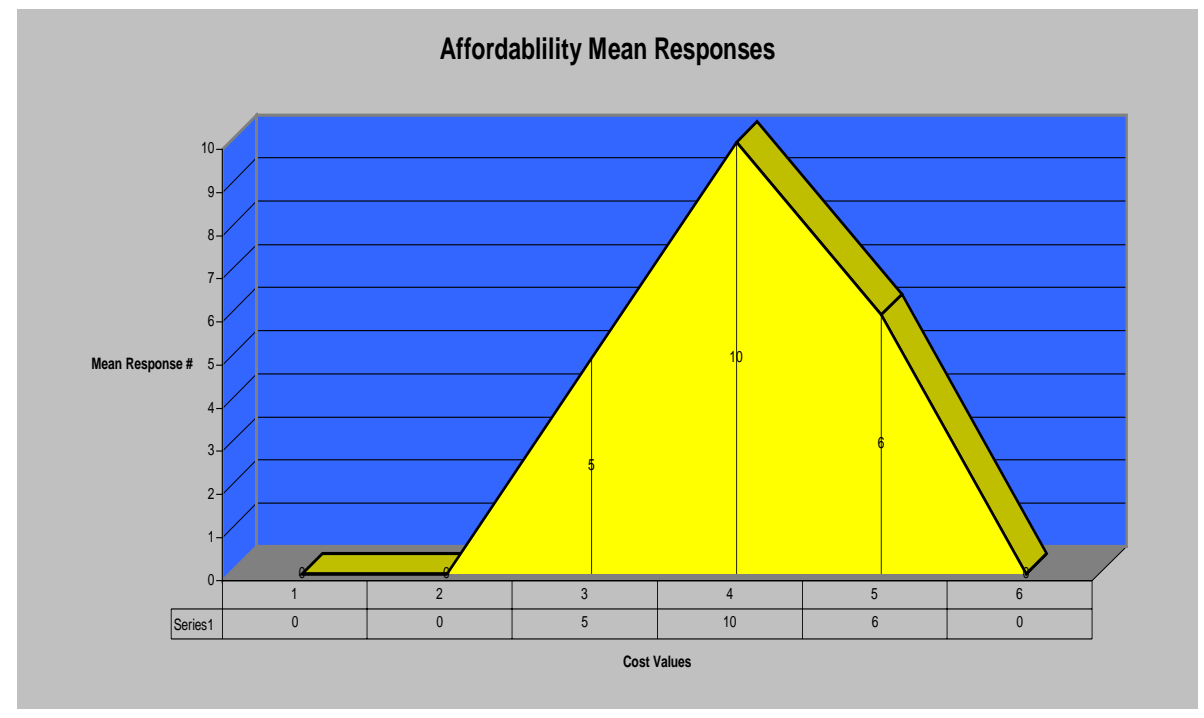

\section{Fig. 5.2. AFFORDABILITY GRAPH}

Affordability was the other characteristic by which the data were grouped. The first two affordability groups, (beyond budget and very expensive) were not among the mean responses. The inference is that the consensus of the panelists is that the twenty-one infrastructures selected are at worse expensive. The chart in chapter 4 indicates a change of opinion during round three in which the largest group (10) had a mean equal to affordable and none of the infrastructures had a mean of cost effective. The other two categories expensive (5) and very affordable (6) were close to being equal. This gives 
rise to a distribution that is skewed towards the affordable side of the scale. The distribution has a mean of 3.86 and a standard deviation of 1.56 which for this study's purpose puts the mean cost factor in the affordable category and a standard deviation that places all means within \pm 1 standard deviation of affordable.

\section{LIFE EXPECTANCY BEYOND 20 YEARS}

The only infrastructure that had a life expectancy beyond 20 years was staff development. While some may not consider this a technology it certainly is an infrastructure which falls into the support category and is deemed to be important by the panel. It is the only identified infrastructure that is projected to continue indefinitely. The affordability distribution placed this item at a mean of 4.44 , which is half way between, affordable and very affordable. This is the ideal technology infrastructure for a school system because it is affordable and is projected to last for a long time.

The charts below indicate that the business people and the educators on the panel agree that staff development (\#1) will last beyond 20 years and that it is on the affordable side of the scale. 
Table 5.2

Business/Educator Comparrison

Life Expectancy

$\begin{array}{lllll}1-5 & 6-10 & 11-15 & 16-20 & 20+\end{array}$

years years years years years Mean

(5)

(4)

(3)

(2)

(1)

\#1 Staff Development

$\begin{array}{lllllll}\text { Business } & 1 & 1 & 3 & 3 & 1 & 2.78 \\ \text { Educator } & 0 & 1 & 3 & 1 & 4 & 2.11\end{array}$

Table 5.3

Business/Educator Comparrison

Affordability

BB VE EX AF VA CE MEAN

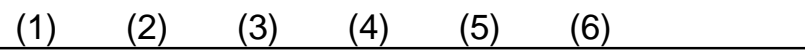

\section{Staff Development}

$\begin{array}{llllllll}\text { Business } & 1 & 1 & 3 & 3 & 1 & 4 & 4.78 \\ \text { Educator } & 1 & 1 & 1 & 2 & 1 & 3 & 4.11\end{array}$

The table 5.3 indicates that the educators see this infrastructure as more expensive than do the business individuals. This could be attributed to the smaller budgets to which the educators have access.

\section{LIFE EXPECTANCY OF 16 TO 20 YEARS}

The six technology infrastructures that have mean time frames of 16 to 20 years are the following: (\#2) File Servers, (\#3)Wireless Networks, (\#4) Help Desks, (\#5) Maintenance Contracts, (\#6) Fiber Optics, and (\#7) Anti-Virus Softwares.

The charts that follow will illustrate the relationship of the answers to the questions of life expectancy and affordability, which were provided by the 
expert panel. Notice that in the final group there is the same number of educators responding, as there are business people.

\begin{tabular}{|c|c|c|c|c|c|c|}
\hline & $\begin{array}{c}1-5 \\
\text { years } \\
(5)\end{array}$ & $\begin{array}{c}6-10 \\
\text { years } \\
(4)\end{array}$ & $\begin{array}{c}11-15 \\
\text { years } \\
(3)\end{array}$ & $\begin{array}{c}16-20 \\
\text { years } \\
(2)\end{array}$ & $\begin{array}{c}20+ \\
\text { years } \\
(1)\end{array}$ & Mean \\
\hline \multicolumn{7}{|c|}{ \#2 File Servers } \\
\hline Business & 1 & 1 & 3 & 3 & 1 & 2.78 \\
\hline Educator & 0 & 1 & 3 & 1 & 4 & 2.11 \\
\hline \multicolumn{7}{|c|}{ \#3 Wireless Networks } \\
\hline Business & 0 & 1 & 3 & 2 & 3 & 2.22 \\
\hline Educator & 1 & 0 & 1 & 3 & 4 & 2.00 \\
\hline \multicolumn{7}{|c|}{ \#4 Help Desk } \\
\hline Business & 1 & 0 & 2 & 1 & 5 & 2.00 \\
\hline Educator & 0 & 1 & 2 & 1 & 6 & 1.56 \\
\hline \multicolumn{7}{|c|}{ \#5 Maintenance Contracts } \\
\hline Business & 0 & 0 & 4 & 1 & 4 & 2.00 \\
\hline Educator & 0 & 0 & 0 & 0 & 9 & 1.00 \\
\hline \multicolumn{7}{|c|}{ \#6 Fiber Optics } \\
\hline Business & 0 & 2 & 2 & 2 & 3 & 2.33 \\
\hline Educator & 0 & 3 & 2 & 0 & 4 & 2.44 \\
\hline \multicolumn{7}{|c|}{ \#7 Anti-Virus Softwares } \\
\hline Business & 1 & 2 & 3 & 1 & 2 & 2.89 \\
\hline Educator & 0 & 1 & 1 & 0 & 7 & 1.56 \\
\hline
\end{tabular}

Even though the mean time frame places the six infrastructures listed above into the 16-20 year time frame, the educators and the business people are not in total agreement about maintenance contracts (\#5) and anti-virus software (\#7). All of the educators said that maintenance contracts will be around for more than twenty years, however the business individuals were more conservative and some of them believe that maintenance contracts may only last as long as fifteen years. In either case the time frame is of considerable length which is important to both parties. Educators may be 
relying on the fact that most educational institutions do not have the personnel to perform their own maintenance.

Table 5.5

Business/Educator Comparrison

Affordability

BB VE EX AF VA CE MEAN

$\begin{array}{lllll}(1) & (2) \quad(3) & (4) \quad(5) \quad(6)\end{array}$

\#2 File Servers

$\begin{array}{llllllll}\text { Business } & 0 & 0 & 0 & 4 & 0 & 5 & 5.11\end{array}$

$\begin{array}{llllllll}\text { Educator } & 0 & 0 & 0 & 2 & 0 & 7 & 5.56\end{array}$

\#3 Wireless Networks

$\begin{array}{llllllll}\text { Business } & 2 & 1 & 3 & 2 & 1 & 0 & 2.89\end{array}$

$\begin{array}{llllllll}\text { Educator } & 1 & 1 & 5 & 2 & 0 & 0 & 2.89\end{array}$

\#4 Help Desk

$\begin{array}{llllllll}\text { Business } & 0 & 1 & 4 & 1 & 1 & 2 & 3.89\end{array}$

$\begin{array}{llllllll}\text { Educator } & 0 & 1 & 5 & 0 & 1 & 2 & 3.78\end{array}$

\#5 Maintenance Contracts

$\begin{array}{llllllll}\text { Business } & 0 & 3 & 3 & 3 & 0 & 0 & 3.00\end{array}$

$\begin{array}{llllllll}\text { Educator } & 0 & 1 & 3 & 1 & 1 & 3 & 4.22\end{array}$

\#6 Fiber Optics

$\begin{array}{llllllll}\text { Business } & 0 & 0 & 3 & 3 & 1 & 2 & 4.22\end{array}$

$\begin{array}{llllllll}\text { Educator } & 0 & 2 & 3 & 2 & 2 & 0 & 3.44\end{array}$

\#7 Anti-Virus Softwares

$\begin{array}{llllllll}\text { Business } & 0 & 0 & 0 & 1 & 5 & 3 & 5.22\end{array}$

\begin{tabular}{llllllll} 
Educator & 0 & 0 & 0 & 4 & 0 & 5 & 5.11 \\
\hline
\end{tabular}

Note: $\mathrm{BB}=$ Beyond Budget $\quad \mathrm{AF}=$ Affordable

$\mathrm{VE}=$ Very Expensive $\mathrm{VA}=$ Very Affordable

$\mathrm{EX}=$ Expensive $\quad \mathrm{CE}=$ Cost Effective

When looking at the affordability of maintenance contracts(\#5), fiber optics (\#6), and anti-virus software (\#7) the educators and the business individuals have some differences. Business individuals see the maintenance contracts as being more expensive than do the educators. A reason for this might be that businesses many times have personnel available to do their maintenance and as the architect stated in chapter 4 , it was his experience that his clients could save money by having their own maintenance personnel. 
Fiber optics was seen as more expensive by the educators than the business individuals. This could be a result of not much fiber in use in the educational environment. The third infrastructure, anti-virus software was seen by both groups as affordable, however the educators were more on the conservative end. It is interesting to note that all five categories were represented in this time frame and that the support category was completed in the first two time frames making it a lasting infrastructure.

\section{LIFE EXPECTANCY OF 11-15 YEARS}

The nine technology infrastructures that have mean time frames of 11 to 15 years are the following: (\#8) Palm Computers, (\#9) Wireless Workpads, (\#10) Laptop Computers, (\#11) Shared Networks, (\#12) Switched Networks, (\#13) Voice Communication Software, (\#14) LAN Software, (\#15) LAN to WAN Software, and (\#16) Secure Communication Centers. 
Table 5.6

Business/Educator Comparrison

Life Expectancy

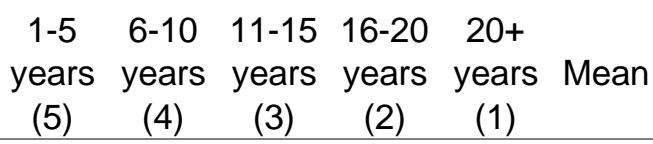

\begin{tabular}{|c|c|c|c|c|c|c|}
\hline \multicolumn{7}{|c|}{ \#8 Palm Computers } \\
\hline Business & 2 & 2 & 3 & 1 & 1 & 3.33 \\
\hline Educator & 2 & 1 & 5 & 0 & 1 & 3.33 \\
\hline \multicolumn{7}{|c|}{ \#9 Wireless Workpads } \\
\hline Business & 3 & 1 & 1 & 2 & 2 & 3.11 \\
\hline Educator & 1 & 1 & 4 & 2 & 0 & 3.13 \\
\hline \multicolumn{7}{|c|}{ \#10 Laptop Computers } \\
\hline Business & 0 & 3 & 2 & 1 & 3 & 2.56 \\
\hline Educator & 1 & 2 & 2 & 1 & 3 & 2.67 \\
\hline \multicolumn{7}{|c|}{ \#11 Shared Networks } \\
\hline Business & 2 & 1 & 3 & 1 & 1 & 3.25 \\
\hline Educator & 0 & 0 & 4 & 2 & 3 & 2.11 \\
\hline \multicolumn{7}{|c|}{ \#12 Switched Networks } \\
\hline Business & 1 & 5 & 3 & 0 & 0 & 3.78 \\
\hline Educator & 2 & 2 & 1 & 1 & 3 & 2.89 \\
\hline \multicolumn{7}{|c|}{ \#13 Voice Communication Software } \\
\hline Business & 0 & 4 & 0 & 3 & 2 & 2.67 \\
\hline Educator & 1 & 4 & 3 & 0 & 4 & 2.44 \\
\hline \multicolumn{7}{|c|}{ \#14 Local Area Network Software (LAN) } \\
\hline Business & 1 & 4 & 2 & 0 & 2 & 3.22 \\
\hline Educator & 0 & 0 & 6 & 1 & 2 & 2.44 \\
\hline \multicolumn{7}{|c|}{ \#15 Local Area to Wide Area Software (LAN - WAN) } \\
\hline Business & 0 & 4 & 3 & 1 & 1 & 3.11 \\
\hline Educator & 0 & 0 & 4 & 2 & 3 & 2.11 \\
\hline \multicolumn{7}{|c|}{ \#16 Secure Communication Centers } \\
\hline Business & 0 & 3 & 2 & 1 & 2 & 2.75 \\
\hline Educator & 2 & 2 & 1 & 1 & 3 & 3.22 \\
\hline
\end{tabular}

Within the time frame of 11-15 years the educators and the business people agreed that five of the infrastructures (palm computers, wireless workpads, laptop computers, voice communication software, and secure communication centers) would last at most fifteen years. The other four infrastructures drew disagreement between the two groups. Shared networks, LAN software, and LAN to wan software were believed to fit the category by the business people while the educators conjectured that these infrastructures 
would last for a longer period of time. Educators are not used to replacing their software frequently and thus may attribute a longer life to some of those products. The switched network infrastructure had the educators placing it within the time frame while the business people believed that a shorter time period (6-10 years) was more appropriate.

This time frame is made up of three pieces of equipment, two network devices, three softwares, one communication structure, and zero support devices. The networks, the softwares, and the communication structures are all infrastructures that can be integrated and are believed to have a projected life span of more than ten years. The equipment devices can also be integrated into the network structure. From this data it is not hard to argue that sudden change from the present infrastructures is not projected. 
Table 5.7

Business/Educator Comparrison

Affordability

BB VE EX AF VA CE MEAN

$\begin{array}{lllll}(1) & (2) \quad(3) \quad(4) \quad(5) \quad(6)\end{array}$

\begin{tabular}{|c|c|c|c|c|c|c|c|}
\hline \multicolumn{8}{|c|}{ \#8 Palm Computers } \\
\hline Business & 1 & 3 & 2 & 3 & 0 & 0 & 2.78 \\
\hline Educator & 2 & 1 & 6 & 0 & 0 & 0 & 2.44 \\
\hline \multicolumn{8}{|c|}{ \#9 Wireless Workpads } \\
\hline Business & 1 & 3 & 3 & 2 & 0 & 0 & 2.67 \\
\hline Educator & 1 & 1 & 6 & 0 & 0 & 0 & 2.63 \\
\hline \multicolumn{8}{|c|}{ \#10 Laptop Computers } \\
\hline Business & 0 & 3 & 3 & 3 & 0 & 0 & 3.00 \\
\hline Educator & 0 & 3 & 3 & 3 & 0 & 0 & 3.00 \\
\hline \multicolumn{8}{|c|}{ \#11 Shared Networks } \\
\hline Business & 0 & 0 & 1 & 2 & 2 & 4 & 5.00 \\
\hline Educator & 0 & 2 & 0 & 2 & 1 & 4 & 4.56 \\
\hline \multicolumn{8}{|c|}{ \#12 Switched Networks } \\
\hline Business & 0 & 0 & 4 & 3 & 1 & 1 & 3.89 \\
\hline Educator & 0 & 0 & 3 & 5 & 0 & 1 & 3.89 \\
\hline \multicolumn{8}{|c|}{ \#13 Voice Communication Software } \\
\hline Business & 0 & 2 & 0 & 5 & 1 & 1 & 3.89 \\
\hline Educator & 0 & 0 & 3 & 2 & 1 & 3 & 4.44 \\
\hline \multicolumn{8}{|c|}{ \#14 Local Area Network Software (LAN) } \\
\hline Business & 0 & 0 & 1 & 4 & 4 & 1 & 4.33 \\
\hline Educator & 0 & 1 & 0 & 5 & 1 & 2 & 4.33 \\
\hline \multicolumn{8}{|c|}{ \#15 Local Area to Wide Area Software (LAN-WAN) } \\
\hline Business & 0 & 0 & 2 & 4 & 3 & 0 & 4.11 \\
\hline Educator & 0 & 3 & 1 & 2 & 1 & 2 & 3.78 \\
\hline \multicolumn{8}{|c|}{ \#16 Secure Communication Centers } \\
\hline Business & 0 & 2 & 4 & 2 & 1 & 0 & 3.22 \\
\hline Educator & 0 & 3 & 3 & 2 & 0 & 1 & 3.22 \\
\hline
\end{tabular}

Looking at affordability in the 11-15 year time frame category we find close agreement between the educators and the business people when discussing wireless workpads (\#9), laptop computers (\#10), switched networks (\#12), LAN software (\#14), and secure communications centers (\#16). In the categories of wireless workpads, laptop computers, and secure communication centers both groups agree as to life expectancy and affordability of the infrastructure. The group agrees that these infrastructures 
will exist between 11 and 15 years and are somewhere between affordable and expensive. The educators seem to think that given categories have higher price tags on them than the business people think they have. Again, it seems as though this is a function of budget availability.

\section{LIFE EXPECTANCY OF 6-10 YEARS}

There are five infrastructures that have a mean time frame of 6 to 10 years. They are: (\#17) network hubs, (\#18) electronic whiteboards, (\#19) CAT-5 wiring, (\#20) proxy server software, and (\#21) Windows software.

Table 5.8

Business/Educator Comparrison Life Expectancy

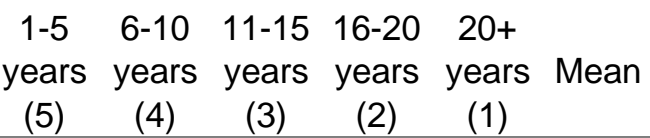

\begin{tabular}{|c|c|c|c|c|c|c|}
\hline \multicolumn{7}{|c|}{ \#17 Network Hubs } \\
\hline Business & 2 & 5 & 1 & 0 & 1 & 3.78 \\
\hline Educator & 3 & 3 & 2 & 1 & 0 & 3.89 \\
\hline \multicolumn{7}{|c|}{ \#18 Electronic Whiteboards } \\
\hline Business & 1 & 3 & 4 & 1 & 0 & 3.44 \\
\hline Educator & 3 & 3 & 2 & 0 & 1 & 3.78 \\
\hline \multicolumn{7}{|c|}{ \#19 CAT- 5 Wiring } \\
\hline Business & 3 & 3 & 3 & 0 & 0 & 4.00 \\
\hline Educator & 1 & 6 & 1 & 0 & 0 & 4.00 \\
\hline \multicolumn{7}{|c|}{ \#20 Proxy Server } \\
\hline Business & 0 & 9 & 0 & 0 & 0 & 4.00 \\
\hline Educator & 2 & 4 & 1 & 1 & 1 & 3.56 \\
\hline \multicolumn{7}{|c|}{ \#21 Windows Software } \\
\hline Business & 2 & 4 & 3 & 0 & 0 & 3.89 \\
\hline Educator & 2 & 4 & 1 & 0 & 2 & 3.44 \\
\hline
\end{tabular}


Both the business people and the educators agree on the placement of three of the five infrastructures. They agree that network hubs (\#17), CAT-5 wiring (\#19), and proxy servers (\#20) will last for approximately 6 to 10 years. In the case of electronic whiteboards (18), the business people project that they will last a little longer. The other technology, Windows software (\#21) is thought to be able to last a little longer by the educators. In a chapter 4 comment one of the respondents remarked that "Therefore, since their market penetration is so great, I think Windows (or it's next version NT Workstation Professional that MS has already announced will replace Windows 98, and subsequent iterations,) will be around for a long time." The disparity may exist because of the individual's definition of Windows.

Table 5.9

Business/Educator Comparrison

Affordability

BB VE EX AF VA CE MEAN

$\begin{array}{lllll}(1) & (2) & (3) & (4) & (5)\end{array}$

\begin{tabular}{|c|c|c|c|c|c|c|c|}
\hline \multicolumn{8}{|c|}{ \#17 Network Hubs } \\
\hline Business & 0 & 2 & 0 & 4 & 1 & 2 & 4.11 \\
\hline Educator & 0 & 1 & 2 & 2 & 1 & 3 & 4.33 \\
\hline \multicolumn{8}{|c|}{ \#18 Electronic Whiteboards } \\
\hline Business & 0 & 1 & 3 & 3 & 1 & 1 & 3.78 \\
\hline Educator & 1 & 0 & 4 & 1 & 2 & 1 & 3.67 \\
\hline \multicolumn{8}{|c|}{ \#19 CAT- 5 Wiring } \\
\hline Business & 0 & 0 & 0 & 2 & 5 & 1 & 4.88 \\
\hline Educator & 0 & 0 & 1 & 4 & 2 & 2 & 4.56 \\
\hline \multicolumn{8}{|c|}{ \#20 Proxy Server } \\
\hline Business & 0 & 0 & 2 & 4 & 2 & 1 & 4.22 \\
\hline Educator & 0 & 0 & 1 & 3 & 1 & 4 & 4.89 \\
\hline \multicolumn{8}{|c|}{ \#21 Windows Software } \\
\hline Business & 0 & 0 & 1 & 4 & 3 & 1 & 4.44 \\
\hline Educator & 0 & 0 & 0 & 4 & 2 & 3 & 4.89 \\
\hline
\end{tabular}


Table 5.9 illustrates that with one exception none of the panelists thought that any of the infrastructures in this category were beyond their budget. Close agreement was reached in three of the five categories including: network hubs (\#17), electronic whiteboards (\#18), and CAT-5 wiring (\#19). Network hubs and CAT-5 wiring were infrastructures that the two groups agreed had the same time frame and affordability. In the case of the proxy server (\#20) and the Windows software (\#21) were considered to be less expensive by the educators a fact that might be explained by the different environments. In any case the panel considered this group of infrastructures on the affordable side of the scale.

One other comparison scenario is to look at the life expectancy charted with the affordability of each infrastructure. Since there are five life expectancy time frames and six affordability categories, the total possible different results is thirty. Of the thirty possibilities the data in this study was grouped into only nine. When looking at life expectancy categories 1-5 years is the least desirable and $20+$ years is the most desirable. In the affordability categories Beyond Budget is the least desirable and Cost Effective is the most desirable. Therefore, the most desirable infrastructure would be one which will last 20+ years and be Cost Effective while the least desirable infrastructure would be one which will last 1-5 years and be Beyond Budget. In this study none of the infrastructures were placed in either of the above combinations. 
What did occur was the following:

(\#7) Anti-Virus Software is Very Affordable and has a life expectancy of 16-20 years.

- $\quad$ (\#1) Staff Development is Affordable and has a life expectancy of $20+$ years.

- $\quad$ (\#2) File Servers and (\#11) Shared Networks are Very Affordable and have a life expectancy of 11-15 years.

- $\quad$ (\#4) Help Desk and (\#6) Fiber Optics are Affordable and have a life expectancy of 16-20 years.

- $\quad$ (\#12) Switched Networks, (\#13) Voice Communication Software, (\#14) LAN Software, and (\#15) LAN to WAN Software are Affordable and have a life expectancy of 11-15 years.

- $\quad$ (\#3) Wireless Networks and (\#5) Maintenance Contracts are Expensive and have a life expectancy of 16-20 years.

- $\quad$ (\#19) CAT-5 Wiring, (\#20) Proxy Server Software, and (\#21) Windows Software are Very Affordable and have a life expectancy of 6-10 years.

- $\quad$ (\#8) Palm Computers, (\#9) Wireless Workpads, (\#10) Laptop Computers and (\#16) Secure Communication Centers are Expensive and have a life expectancy of 11-15 years.

- $\quad$ (\#17) Network Hubs and (\#18) Electronic Whiteboards are Affordable and have a life expectancy of 6-10 years.

The above data suggests that the worse case scenario is that an identified infrastructure is "Expensive" and the shortest life expectancy for any is 6-10 years.

\section{Scenario Summary}

The scenario was organized by first giving the reader a time frame chart and an affordability chart for an overall view of the data collected. Then the infrastructure data were presented in four time frames: beyond 20 years, 16-20 years, 11-15 years, and 6-10 years. The $0-5$ year category was not included since none of the data fell within this time frame. Within these time frames the results from the business community and the educational community were compared and comments were presented. 
Several ideas surfaced which were common across the time frames and occasionally common between the business and education individuals. In most cases the educators on the panel rated the infrastructures more costly than did the business persons. Both groups agreed that staff development would outlast the rest of the infrastructures probably because of its ever-changing nature. The businesses see more of a return on their investment in staff development than do the educators thus making it less expensive to business.

All of the support infrastructures were projected to last beyond 15 years and the issues of networks and connectability are also included in this time frame. Some of the panelist commented that their answers depended upon their definitions of the individual infrastructures.

Finally, a comparison of the life expectancy and affordability of each infrastructure was presented. This organization of the data emphasized the fact that none of the panelists thought any of the identified infrastructures were beyond the budget or very expensive and that all would last at least 5 years.

\section{Summary}

The purposes of this study were to apply the Delphi technique to technology infrastructure planning for the construction of a new high school or the renovation of an existing structure and to develop a Life Expectancy/Affordability scenario using selected generated infrastructures. Also to compare the responses of the business community members of the panel with the responses of the educational community members of the panel. 
This author has spent a significant portion of his career working with technology in a high school environment. It was surprising that the expert panel did not include the Internet as an infrastructure. Most of what we do today includes the Internet in some manner. This entire study was done by accessing research material at various colleges and universities through their Internet connection. The correspondence with the experts was through E-mail on the Internet. Communication with West Virginia University was by E-mail on the Internet. Internet and future versions of the same will have a huge impact on everyone's life.

This author was not surprised when the data suggested that staff development was the most affordable and longest lasting technology infrastructure that could be implemented.

\section{Collection of Data}

The data were gathered in three rounds during the data collection phase. Round 1 generated a "pool" of infrastructures to which the panel of experts responded during Rounds 2 and 3. Twenty-one different infrastructures were identified during Round 1 by the twenty-one of the twenty-five original panelists. During Round 2 and Round 3 eighteen panelists responded. Nine of the panel of experts was employed in business (one was located in Ireland) and nine were employed in educational settings. The study was conducted between January 15, 1999 and March 17, 1999. 


\section{Treatment of Data}

Round 1 data were collected and like responses were combined. The author then presented a list of twenty-one infrastructures to the panelists. Upon receiving the Round 2 responses the author calculated the mean response and standard deviation for each infrastructure for both life expectancy and affordability. This data were used to determine a consensus response. The panelists in Round 3 were given a list of the infrastructures and the consensus responses. Also included were the panelists original responses. They were asked to indicate a willingness to agree with the consensus response or support their original response. The Round 3 data were organized in charts to prepare the reader for the Scenario.

\section{Conclusions}

Within the limitations of this study the following conclusions seem warranted:

1. The Delphi technique used in this study was an appropriate and effective instrument for the exploration of the future implementation of technology infrastructures in building or renovating a high school facility.

The quantity and quality of the responses from an extremely busy group of individuals indicates the level of concern for the implementation of technology infrastructures in high schools.

Communicating through several rounds allowed for a minimal amount of misinterpretations concerning the different technology infrastructures.

2. The diversity and credentials of the expert panel coupled with the ability to derive consensus without having the individuals in the same room added to the 
validity of the collected data. Since the panel included representatives of domestic and foreign corporations, state department of education, governor's office of technology, local school systems, and an architect, in this sense, this study was representative and complete.

3. The content of this study suggests that several areas in the development of technology infrastructures will not change immediately and the current infrastructures are somewhat affordable. Also suggested is a closer agreement among educators and business people as to life expectancy and affordability of infrastructures than is commonly thought. In a broad sense the term infrastructures (supporting) has been shown to mean more than wires, bricks, and mortar. In fact the strongest suggestion from the data is that staff development is the key infrastructure in both life expectancy and affordability.

4. Connectivity (networks) and support mechanisms (help desk, maintenance, etc.) are important areas as the data for this study points to a relatively long life expectancy (16-20 years) for these infrastructures while remaining affordable.

\section{Recommendations}

A number of recommendations have been suggested as a result of this study:

1. That persons responsible for the building or renovating of high schools in West Virginia take a serious look at technology infrastructures which are to be implemented in the construction phase or renovation phase of high schools. 
2. That adequate staff development concerning technology be provided with the implementation of new or existing technologies and that these training sessions would include information about connectivity.

3. That the education community partner with the business community and share the expertise of each group.

4. That a follow-up study be conducted in five years to determine the reliability and validity of the projections contained in this study and to determine what new directions technology is taking.

5. That a similar study be conducted using a different and expanded expert panel to determine the degree of agreement among those working in the field.

6. That a similar study be conducted in West Virginia addressing the notion of availability of technologies in different high school settings.

7. That a similar study be conducted in West Virginia using high school administrators, county office administrators, and high school teachers as members of the expert panel.

8. That a similar study be conducted increasing the number of participants on the expert panel in order to see if others concur with the original panel on the agreement between business and education.

9. That a similar study be conducted using middle school and high school teachers and administrators as the panel. This study could investigate the feelings of the practitioners. 
10. That a similar study be conducted adding the categories of "New

Construction" and "Renovation". The purpose would be to see if the thinking changes when considering these two options. 


\section{WORKS CITED}

Allen, John R., 1973,"The Cybernetic Centaur: Advances in Computer Assisted Instruction", Computers and the Humanities 7 n6 (Sep/Nov) 373-387, First Search, ERIC, EJ098145.

Arnold, David, 1997. "Taking Control", School Planning and Management 36 n6 (June) 20-24, ERIC Document Reproduction Service, Accession No EJ548931.

Aten, Betty M. 1996. "An Analysis of the Nature of Educational Technology Leadership in California's SB 1274 Restructuring Schools", University of San Francisco, San Francisco, First Search, Dissertation Abstracts Online, Accession No. AAG9626215.

Bailey, Gerald D. 1997. "What Technology Leaders Need to Know: The Essential Top 10 Concepts for Technology Integration in the $21^{\text {st }}$ Century" Learning and Leading with Technology 25 n1 57-62 (September), First Search, ERIC, Clearinghouse Number IR535576.

Balow, Nancy, 1998. "Why Bring the Internet into the Classroom?", The Link 17 n3(Fall) 1-3, Charleston, WV, Appalachian Educational Laboratory.

Bartolutti, Steven, and Jane Clayton, 1998. "The Greed (Need?) for Speed". BICSI Fall Conference, 1998. Available from www.bicsi.org/prsump33.htm; INTERNET.

Bissette, Marie. 1998. "Investigation of Technology Integration in a Rural School District", The University of New Mexico, First Search, Dissertation Abstracts Online, Accession No. AAG9826602.

Bloomfield, Masse, 1995. The Automated Society; What the Future Will Be and How We Will Get it That Way. Canoga Park: Masefield Books.

Boisso, Dale Edward. 1996. "Infrastructural Spillover Effects: Cross-Section and time Series Evidence", First Search, Dissertation Abstracts Online, Accession No. AAG9628668.

Brown, Wayne William, Jr. 1996. "Educational Technology: Factors Affecting Its Use in Rural School Distrcts in Colorado", Colorado State University, First Search, Dissertation Abstracts Online, Accession No. AAG9719553. 
Bryan, Joyce Bethea. 1998. " Technological Literacy Assessment in Secondary Schools Through Portfolio Development", Nova Southeastern University, First Search, Dissertation Abstracts Online, Accession No. AAG9840746.

Burdin, Joel L., Comp.; And Others, 1974. Forecasting the Educational Future. Washington, D.C.: ERIC Clearinghouse on Teacher Education, First Search, ERIC, ED091343.

Burkhart, Nancy N. 1996. "Perceptions of the Use of E-mail to Facilitate Communications in a Large Urban School District", Baylor University, First Search, Dissertation Abstracts Online, Accession No. AAG9708205.

Carstens, James E. 1995. "The Implementation of Microcomputers and Related Technologies in a Secondary School: A Case Study", New York University, New York, First Search, Dissertation Abstracts Online, Accession No. AAI9603280.

Cetron, Marvin J., and Owen Davies. 1984. American Renaissance, Our Life at the Turn of the $21^{\text {st }}$ Century. New York: St. Martin's Press.

Cetron, Marvin J., and Margaret Gayle. 1991. Educational Renaissance, Our Schools at the Turn of the Twenty-First Century. New York: St. Martin's Press.

Christy, Shelia Ann Colley. 1997. "Future Developments of Computer Network Technologies in K-12 Educational Environments". University of Missouri, Columbia. First Search, Dissertation Abstracts Online, Accession No. AAG9842520.

Clinton, Bill. 1990. "Schools Must Be Restructured." In America's Future: Opposing Viewpoints. Eds. William Dudley and Bonnie Szumski, 178-183. San Diego: Greenhaven Press.

Coffman, William E., Ed., 1973. "Frontiers of Educational Measurement and Information Systems-1973", Conference Proceedings, First Search, ERIC, ED091442.

Cooke, Paula Ruth. 1995. "Student and Faculty Perceptions of a Notebook Computer-based Instructional System: A Case Study", The University of North Dakota, First Search, Dissertation Abstracts Online, Accession No. AAI9623663.

Dean, Martha. 1994. "School Improvement Councils in West Virginia," Doctoral dissertation, Morgantown, West Virginia University. 
Dede, Chris. 1997. "Rethinking How To Invest in Technology". Educational Leadership 55. n3 (Nov.) 12-16, ERIC Reproduction Service, Accession No. EJ553827.

Dillon, Connie Lee Greb. 1980. "Education for the Future: Implications for Educational Technology", The University of Oklahoma, First Search, Dissertation Abstracts Online, Accession No. AAG8027512.

Derwin, Michael W, 1995."Infrastructures for the Evolving Classroom (Cabling Systems for Schools. BICSI Fall Conference, 1995. Available from www.bicsi.org/libfall 2.htm; INTERNET.

Dulaney, Jack C. 1980. "The Impact of Future-Oriented Information on Predicting Curricular Needs in Public Schools," West Virginia University, Morgantown. First Search, Dissertation Abstracts Online, Accession No. AAG8029271.

EDRS, 1997. "Educational Technology Goals, Progress, and Recommended Actions", Report, ERIC Document Reproduction Service,Clearinghouse Number IR018747.

"Fabulous Facilities: New Constructions and Renovations". 1997. American Libraries 28 n4 (April) 38-48, ERIC Reproduction Service, Accession NO. EJ543180.

Flinchbaugh, Robert W. 1993. The $21^{\text {st }}$ Century Board of Education, Lancaster, Technomic. 169.

Flinchbaugh, Robert quoted in Friebel, Carl H. 1998. "An Application of the Delphi Method of Forecasting to the Future of Public Education in West Virginia", Dissertation Prospectus, West Virginia University, Morgantown.

Friebel, Carl H. 1999. "An Application of the Delphi Method of Forecasting to the Future of Public Education in West Virginia", Doctoral Dissertation, West Virginia University, Morgantown.

Fries, Bedelia and Brian Monahan. 1998. "School District Technology Planning in an Era of Rapid Change". Educational Technology 38 (Jan-Feb):60-62, ERIC Reproduction Service, Accession No. EJ559838.

Gates, Bill. 1995. The Road Ahead. Middlesex, England: Penguin Books.

Greenawalt, II, Charles E. ed. 1994. Educational Innovation: An Agenda to Frame the Future. New York: University Press of America. 
Herman, J.J., J.L. Herman quoted in Webber, Charles F. 1995. "School Board Members' Perceptions of the Future: Patterns and Implications," United States Department of Education, Office of Educational Research and Improvement (OERI), Washington. p.5 ERIC Document Reproduction Service, \#383110.

Hickox, Katie. 1997. "5 Trends Your Job Depends On". 1997. Electronic Learning 16 n4 (Feb.) 32-34, 36-38, 50, ERIC Document Reproduction Service, Accession No EJ559723.

Hoy, Wayne K. and Cecil G. Miskel, Education Administration: Theory, Research and Practice (New York, McGraw-Hill, 1996).

Information Technology Research: Investing in Our Future. 1999. President's Information Technology Advisory Committee. Arlington, VA: National Coordination Office for Computing, Information, and Communications.

Jones, Raymond Thomas. 1997. "Prediction of Educational Technology to be Found in the Public Schools of the Year 2000: A Delphi Study (Computers, World Wide Web, E-mail, Multimedia)", Virginia Polytechnic Institute and State University, Blacksburg. First Search, Dissertation Abstracts Online, Accession No. AAG9726297.

Jones, Rita S. 1984. "Schooling for the $21^{\text {st }}$ Century: A Delphi Study of Future Issues in Education a Identified by Educational Planners," University of Pennsylvania, Philadelphia. First Search, Dissertation Abstracts Online, Accession No. AAG8416368.

Kerr, Stephen T. 1996 Technology and the Future of Schooling. Chicago: National Society for the Study of Education.

Kimball, David. 1996. "Technology Planning in California Schools: Planning for Success or Destined for Failure?", University of Southern California, First Search, Dissertation Abstracts Online, Accession No. AAG9636719.

Leigh, Patricia Randolph. 1997. "The Sins of the Father: An Historical Analysis of Race and Class Equality in Educational Resource Allocation and the Implications for Future Educational Technology Distribution", Iowa State University, First Search, Dissertation Abstracts Online, Accession No. AAG9725461.

Lizardo, Mercedes Magdalena. 1997. "Two Essays on the Distribution of Information Technology Infrastructure in the United States", University of Illinois at Urbana, Champaign, First Search, Dissertation Abstracts Online, Accession No. AAG9812685. 
Lundin, John Howard. 1998. "Contextual Determinants of Media Choice and Communication Infrastructure: A Mechanistic Perspective (Information Technology)". The University of Texas at Arlington, Arlington, First Search, Dissertation Abstracts Online, Accession No. AAG9836589.

Mann, Dale and Judith Lawrence. 1984. "A Delphi Analysis of the Instructionally Effective School," United States Department of Education, Office of Educational Research and Improvement (OERI), ERIC Document Reproduction Service, Accession NO. ED249580.

Maxwell, Leigh Tarvin. 1996. "Community Leader Perspectives on Education, Assessment and Communication Technology: Profiles of Three Ohio Schoolnet Communities", The Ohio State University, Columbus, First Search, Dissertation Abstracts Online, Accession No. AAG9639302.

McClure, Patricia Head. 1996. "Computer-related Technology Use in the High School Physics Classroom: A Case Study", Virginia Polytechnic Institute and State University, Blacksburg, First Search, Dissertation Abstracts Online, Accession No. AAG9719920.

Miller, Sandra Ramos. 1995. "A Delphi Study of the Trends or Events That Will Influence the Content of Curriculum and the Technological Delivery of Instruction in the Public Elementary School in the Year 2005". University of La Verne. First Search, Dissertation Abstracts Online, Accession No. AAI9606393.

Millett, John D., 1974. New Dimensions in Managing the Educational Enterprise, Washington, D.C., Academy for Educational Development, Inc., First Search, ERIC, ED089563.

Milou, Eric. 1998. "Attitudes Toward and Use of the Graphing Calculator in the Teaching of Algebra", Temple University, First Search, Dissertation Abstracts Online, Accession No. AAG9838516.

Montessoro, Pier Luca, 1998. "Evaluating the Speed-to-the-Desk Requirements: The Human Factor". BICSI Fall Conference, 1998. Available from www.bicsi.org/gersum7.htm; INTERNET.

Morgan, Alan D. 1995. "Perceptions by Chief State School Officers of Short and Long Range Priority Issues Confronting Public Education in the Years 2000 and 2020", University of Nevada, Reno, First Search, Dissertation Abstracts Online, Accession No. AAG9631383. 
National Coalition for Technology in Education and Training. 1997. "Educational Technology Goals, Progress, and Recommended Actions, 1997. ERIC Document Reproduction Service, Accession No. ED417693.

O'Donnell, Peggy. 1988. "Preparing Schools for the Year 2000. The Impact of Technology on America's Classrooms in the Decade Ahead," United States Department of Education, Office of Educational Research and Improvement (OERI), ERIC Document Reproduction Service, Accession No. ED302223.

Oliver, James. 1997. "Ten 'Must Ask' Questions When Developing a Technology Plan". School Administrator 54 n4 (April) 26-29, ERIC Document Reproduction Service, Accession No EJ544293.

Olsen, Fred A., 1974. "Philosophy, Technology, and Industrial Arts in an Era of Rapid Change," Man/Society/Technology, 33 n6 (March) 172-176, First Search, ERIC, EJ092369.

O'Shell, Wallace D. 1986."A Delphi Study of the Future Activities of the School Psychologist as Perceived by Superintendents, School Board Members, School Psychologists and Trainers of School Psychologists," University of Pittsburgh, Pittsburgh. First Search, Dissertation Abstracts Online, Accession No. AAG8620307.

Padro, Susan. 1978. "Survey of Staff Development and Curriculum Services for Quality Education, Part II - Delphi Studies on Curriculum Services and Quality Education," United States Department of Education, Office of Educational Research and Improvement (OERI), ERIC Document Reproduction Service, Accession No. ED197442.

Phillips, C. W. and G. B. Oddie, 1974. Industrialised Building Systems Educational Objectives and the Problem of Change. Programme on Educational Building 5, Paris, France, Organisation for Economic Cooperation and Development, Paris, First Search, ERIC, ED089563.

Potter, Gregory Carson. 1981. "An examination of Three Perspectives on the Future of Science and Technology", Rutgers The State University of New Jersey, New Brunswick, First Search, Dissertation Abstracts Online, Accession No. AAG8120848.

Quist, Terry John. 1997. "A Delphi Study Identifying Future Educational Opportunities in Small, Rural Minnesota School Districts", University of Minnesota, First Search, Dissertation Abstracts Online, Accession No. AAG9738471. 
Reynolds, Karen. 1997. "A School of Our Own: Where the Children Live", University of Alberta, Canada, First Search, Dissertation Abstracts Online, Accession No. AAGNQ21625.

Saba, Simon. 1998. "Expectations for and Experience with Telecommunications Technologies in the Teaching and Learning Processes (High School)", First Search, Dissertation Abstracts Online, Accession No. AAG9831996.

Salomon, Gavriel, and David Perkins. 1996. "Learning in Wonderland: What Do Computers Really Offer Education?" In Technology and the Future of Schooling, Stephen T. Kerr, 111-130. Chicago: National Society for the Study of Education.

Seguin, Cynthia Anast. 1995. "Teacher Use of the Electronic Information Highway (Internet) for Curriculum and Instruction and Professional Activities", University of South Dakota, First Search, Dissertation Abstracts Online, Accession No. AAG9801585.

Shapiro, Stuart S. 1990. "Computer Software as Technology: An Examination of Technological Development", Carnegie-Mellon University, First Search, Dissertation Abstracts Online, Accession No. AAG9026782.

Silberman, Harry F., 1971. Some Reservations about the Application of Technology to Increase Productivity in Education, Washington, D. C., National Institute of Education, First Search, ERIC, ED088773.

Smith, Alana Deniese. 1997. "The Role of Art in Restructured Schools: A Case Study of Two Restructured High Schools", Indiana University, First Search, Dissertation Abstracts Online, Accession No. AAG9810771.

Stead, Floyd L. 1975. "An Application of the Delphi Method of Forecasting to Nursing Education Planning in West Virginia, Doctoral Dissertation, West Virginia University, Morgantown.

Webber, Charles F. 1995. "School Board Members' Perceptions of the Future: Patterns and Implications," United States Department of Education, Office of Educational Research and Improvement (OERI), Washington. p.5 ERIC Document Reproduction Service, \#383110.

Whelan, Carol and Others. 1997. "A Qualitative Evaluation of a Statewide Networking Infrastructure in Education Project." Journal of Research on Computing in Education 29 n 4 (Summer) 403-433, ERIC Document Reproduction Service, Accession No EJ547885. 
Wilson, Catherine Temple. 1996. "Teachers' Perceptions Toward $21^{\text {st }}$ Century Technology Implementation in the Shelby County Schools, Tennessee, First Search, Dissertation Abstracts Online, Accession No. AAG9705711. 


\title{
APPENDIX A
}

THE FUTURE OF TECHNOLOGY INFRASTRUCTURE IN WEST VIRGINIA HIGH SCHOOLS

\author{
ROUND 1 \\ CORRESPONDENCE \\ AND \\ RESPONSE SHEET FORMAT
}




\section{WILLIAM H. CARMAN 27 FAIRLAWN DRIVE BUCKHANNON, WV 26201 \\ Whcarman@msys.net \\ January 18, 1999}

Expert Panel Members:

Thank you for agreeing to serve on my expert panel for my Delphi Study. My prospectus meeting is Tuesday, January 19, 1999 at which time full permission for my study should be sanctioned by West Virginia University. As soon as possible I will be sending the initial survey which will ask you to list known technology infrastructures which could be used in a high school. For the purposes of this study, I am using a very broad definition of infrastructure. This could include training for teachers. Please think about this question.

I want to point out several things to you before the study begins.

1. Your participation is entirely voluntary and you do not have to respond to every item or question;

2. Your responses will remain anonymous and confidentiality will be maintained;

3. I will distribute to each of you a copy of the executive summary of the results.

Thank you for agreeing to participate in this study.

William H. Carman 
College of Human Resources and Education

January 20, 1999

\title{
APPLICATION OF THE DELPHI METHOD OF FORECASTING TO THE FUTURE OF TECHNOLOGY INFRASTRUCTURE IN WEST VIRGINIA HIGH SCHOOLS
}

Please answer the following question and return to me by E-mail by January $29^{\text {th }}$. For the purposes of this study the term infrastructure is to be used in a broad sense. Please feel free to be creative, as I believe infrastructure can include training for teachers, and technologies which may be around for a long period of time. I wish to emphasize that your participation is entirely voluntary and you do not have to respond to every item or question. Your responses will remain anonymous and confidentiality will be maintained. Also I plan to distribute to each of you a copy of the executive summary of the results. Again, thank you for agreeing to participate in this study.

\section{William H. Carman}

\section{Whcarman@msys.net}

\section{Round One Question:}

List as many technology infrastructures as possible that could be implemented in the construction of a new high school or the renovation of an existing structure. Remember to use the term infrastructure in a broad sense.

\author{
Educational Leadership Studies - Educational Psychology - \\ Social and Cultural Foundations - Technology Education \\ (Phone) 304 293-3049 - (Fax) 304 293-2279 - PO Box 6122 Allen Hall - Morgantown WV26506-6122 \\ Equal Opportunity / Alternative Action Institution
}




\section{APPENDIX B}

THE FUTURE OF TECHNOLOGY INFRASTRUCTURE IN WEST VIRGINIA HIGH SCHOOLS

ROUND 2

CORRESPONDENCE AND

RESPONSE SHEET FORMAT 


\section{AN APPLICATION OF THE DELPHI METHOD OF FORECASTING TO THE FUTURE OF TECHNOLOGY INFRASTRUCTURE IN WEST VIRGINIA HIGH SCHOOLS}

Please answer the following question and return to me by E-mail by February 8th. I wish to emphasize that your participation is entirely voluntary and you do not have to respond to every item or question. Your responses will remain anonymous and confidentiality will be maintained. Also I plan to distribute to each of you a copy of the executive summary of the results. Again, thank you for agreeing to participate in this study.

\section{Round Two Questions:}

Question One: Consider each of the technology infrastructures listed and decide in your opinion how long these will still be viable technologies. Use the letters associated with the time spans. If you believe a particular technology will never be implemented or will have a very short life span then choose category a.

Question Two: Again consider each technology and determine in your opinion how affordable the technology is for the implementation in West Virginia schools. Use the six point Likert-like scale for your answers. The difference between very affordable and cost effective is that very affordable is something that you have monies for but the item does not increase the efficiency of your budget. Cost effective items increase the efficiency of the budget. If you have questions concerning the categories please contact me.

William H. Carman

Whcarman@msys.net 
Technology \#1 - Question 1

a) 1-5 years b) 6-10 years c) 11-15 years d) 16-20 years e) beyond 20 years Technology \#2 - Question 1

a) 1-5 years b) 6-10 years c) 11-15 years d) 16-20 years e) beyond 20 years

Technology \#1 - Question 2

1) Beyond Budget 2) Very Expensive 3) Expensive

4) Affordable 5) Very Affordable 6) Cost Effective

Technology \#2 - Question 2

1) Beyond Budget 2) Very Expensive 3) Expensive

4) Affordable 5) Very Affordable 6) Cost Effective

William H. Carman

Whcarman@msys.net 


\section{ROUND 2 DELPHI STUDY February 10, 1999}

Expert Panelists: Thank you for all of the creative ideas that you sent in response to the round one question. For those of you who did not contribute any responses I would like you to continue to be a part of the study by responding to round two. Please respond as soon as possible to round two, but no later than February 19, 1999. If this arrives by E-mail remember my E-mail is whcarman@msys.net. If you are receiving a fax, my fax number is (304) 472-0772, which is a shared fax so please include my name on the header sheet.

In the second round I have synthesized the data from round one and am asking you to answer two questions about each piece of data. Question one is to be answered by selecting the appropriate span of years (a, b, c, d, or e). Question two is to be answered by the selecting the appropriate affordability $(1,2,3,4,5$, or 6). Remember your answer is your expert opinion as there are no right or wrong answers.

Question One:

Consider each of the technology infrastructures listed and decide in your opinion how long these will still be viable technologies.

Network Hubs

a) 1-5 years b) 6-10 years c) 11-15 years d) 16-20 years e) beyond 20 years Palm Computers
a) $1-5$ years
b) 6-10 years
c) 11-15 years
d) 16-20 years
e) beyond 20 years

Wirweless Workpad

a) 1-5 years b) 6-10 years c) 11-15 years d) 16-20 years e) beyond 20 years

\section{Laptop Computer}

a) 1-5 years b) 6-10 years c) 11-15 years d) 16-20 years e) beyond 20 years

\section{Electronic Whiteboard}

a) 1-5 years b) 6-10 years c) 11-15 years d) 16-20 years e) beyond 20 years

File Servers

a) 1-5 years b) 6-10 years c) 11-15 years d) 16-20 years e) beyond 20 years

Shared Network

a) $1-5$ years b) $6-10$ years c) $11-15$ years d) $16-20$ years e) beyond 20 years 


\section{Wireless Network}

a) 1-5 years b) 6-10 years c) 11-15 years d) 16-20 years e) beyond 20 years Switched Network

a) 1-5 years b) 6-10 years c) 11-15 years d) 16-20 years e) beyond 20 years

\section{Help Desk}

a) 1-5 years b) 6-10 years c) 11-15 years d) 16-20 years e) beyond 20 years Maintenance Contracts

a) 1-5 years b) 6-10 years c) 11-15 years d) 16-20 years e) beyond 20 years Staff Development and Training

a) 1-5 years b) 6-10 years c) 11-15 years d) 16-20 years e) beyond 20 years

\section{CAT-5 Wiring}

a) 1-5 years b) 6-10 years c) 11-15 years d) 16-20 years e) beyond 20 years Fiber Optic

a) 1-5 years b) 6-10 years c) 11-15 years d) 16-20 years e) beyond 20 years Secure Communications Center

a) 1-5 years b) 6-10 years c) 11-15 years d) 16-20 years e) beyond 20 years Proxy Server Software

a) 1-5 years b) 6-10 years c) 11-15 years d) 16-20 years e) beyond 20 years Windows Software

a) 1-5 years b) 6-10 years c) 11-15 years d) 16-20 years e) beyond 20 years Voice Communication Software

a) 1-5 years b) 6-10 years c) 11-15 years d) 16-20 years e) beyond 20 years Anti-Virus Software

a) 1-5 years b) 6-10 years c) 11-15 years d) 16-20 years e) beyond 20 years LAN Software

a) 1-5 years b) 6-10 years c) 11-15 years d) 16-20 years e) beyond 20 years LAN to WAN Software

a) 1-5 years b) 6-10 years c) 11-15 years d) 16-20 years e) beyond 20 years 
Question Two: 2. Consider each technology and determine in your opinion how affordable the technology is for the implementation in West Virginia schools.

\section{Network Hubs}

1) Beyond Budget 2) Very Expensive 3) Expensive
4) Affordable
5) Very Affordable
6) Cost Effective

\section{Palm Computers}

1) Beyond Budget 2) Very Expensive 3) Expensive

4) Affordable

5) Very Affordable 6) Cost Effective

Wirweless Workpad

1) Beyond Budget 2) Very Expensive 3) Expensive
4) Affordable
5) Very Affordable
6) Cost Effective

\section{Laptop Computer}

1) Beyond Budget 2) Very Expensive 3) Expensive
4) Affordable
5) Very Affordable
6) Cost Effective

Electronic Whiteboard

1) Beyond Budget 2) Very Expensive 3) Expensive
4) Affordable
5) Very Affordable
6) Cost Effective

File Servers

1) Beyond Budget 2) Very Expensive 3) Expensive

4) Affordable 5) Very Affordable 6) Cost Effective

Shared Network

1) Beyond Budget 2) Very Expensive 3) Expensive

4) Affordable 5) Very Affordable 6) Cost Effective

Wireless Network

1) Beyond Budget 2) Very Expensive 3) Expensive

4) Affordable 5) Very Affordable 6) Cost Effective

Switched Network

1) Beyond Budget 2) Very Expensive 3) Expensive

4) Affordable 5) Very Affordable 6) Cost Effective

Help Desk

1) Beyond Budget 2) Very Expensive 3) Expensive
4) Affordable
5) Very Affordable
6) Cost Effective 
Maintenance Contracts

1) Beyond Budget 2) Very Expensive

3) Expensive

4) Affordable

5) Very Affordable

6) Cost Effective

Staff Development and Training

1) Beyond Budget 2) Very Expensive 3) Expensive

4) Affordable 5) Very Affordable 6) Cost Effective

\section{CAT-5 Wiring}

1) Beyond Budget 2) Very Expensive 3) Expensive

4) Affordable 5) Very Affordable 6) Cost Effective

Fiber Optic

1) Beyond Budget 2) Very Expensive 3) Expensive
4) Affordable
5) Very Affordable
6) Cost Effective

Secure Communications Center

1) Beyond Budget 2) Very Expensive 3) Expensive
4) Affordable
5) Very Affordable
6) Cost Effective

Proxy Server Software

1) Beyond Budget 2) Very Expensive

3) Expensive

4) Affordable

5) Very Affordable

6) Cost Effective

Windows Software

1) Beyond Budget 2) Very Expensive 3) Expensive

4) Affordable 5) Very Affordable 6) Cost Effective

Voice Communication Software

1) Beyond Budget 2) Very Expensive 3) Expensive

4) Affordable 5) Very Affordable 6) Cost Effective

Anti-Virus Software

1) Beyond Budget 2) Very Expensive 3) Expensive

4) Affordable 5) Very Affordable 6) Cost Effective

LAN Software

1) Beyond Budget 2) Very Expensive 3) Expensive

4) Affordable 5) Very Affordable 6) Cost Effective

LAN to WAN Software

1) Beyond Budget 2) Very Expensive 3) Expensive

4) Affordable 5) Very Affordable 6) Cost Effective 


\title{
APPENDIX C
}

THE FUTURE OF TECHNOLOGY INFRASTRUCTURE IN WEST VIRGINIA HIGH SCHOOLS

\author{
ROUND 3 \\ CORRESPONDENCE \\ AND \\ RESPONSE SHEET FORMAT
}




\section{AN APPLICATION OF THE DELPHI METHOD OF FORECASTING TO THE FUTURE OF TECHNOLOGY INFRASTRUCTURE IN WEST VIRGINIA HIGH SCHOOLS}

Enclosed you will find the results or the round 2 survey. Also included is a comparison of your responses and the results. For those items that you are in disagreement with by more than one standard deviation please consider your response and either indicate that you wish to change to the response or site reasons why you feel your response is more accurate. This process will help me to include a minority opinion for the data set. Again I wish to emphasize that your participation is entirely voluntary and you do not have to respond to every item or question. Your responses will remain anonymous and confidentiality will be maintained. Thank you for agreeing to participate in this study.

William H. Carman

Whcarman@msys.net 


\section{February 27, 1999 DELPHI STUDY ROUND 3}

Again I would like to thank you for taking time from your busy schedule to assist me with this research. In round one many excellent suggestions were presented. In round two you were asked to consider the life expectancy of individual technologies and the affordability of those technologies. In the final round (round three) you are being provided the results of round two and your responses. In some of the areas your response was different from the consensus opinion and those answers are in boldface type and underlined. Please consider these answers and decide whether you wish to agree with the consensus or support your original response. If you wish to agree with the consensus please indicate by identifying the technology and your new response. If you wish to support your original response please do so by identifying the technology and then a brief statement in support. Remember your responses are voluntary and strict confidence will be maintained. Please return by March 15, 1999.

TECH

NETWORK 1-10

HUB

PALM

COMPUTER

WIRELESS

WORKPAD

LAPTOP

COMPUTER

ELECTRONIC

WHITEBOARD

$1-15$

$11-20$

$11-20$

$1-15$

FILE

$11-20$

SERVER

SHARED

$11-20$

\section{AFFORDABILITY CONSENSUS YOUR QUESTION 2 ANSWER}

Very

Affordable

Expensive

Expensive

Expensive

Expensive

Very

Affordable

Very

Affordable 


\begin{tabular}{|c|c|c|c|}
\hline \multirow{3}{*}{ TECH } & \multirow{3}{*}{$\begin{array}{l}\text { LIFE EXPECTANCY } \\
\text { CONSENSUS YOUR } \\
\text { QUESTION1 ANSWER }\end{array}$} & \multicolumn{2}{|c|}{ AFFORDABILITY } \\
\hline & & CONSENSUS & YOUR \\
\hline & & QUESTION 2 & ANSWER \\
\hline WIRELESS & \multirow[t]{2}{*}{$20+$} & \multirow{2}{*}{\multicolumn{2}{|c|}{ Expensive }} \\
\hline NETWORK & & & \\
\hline SWITCHED & \multirow[t]{2}{*}{$1-10$} & \multirow{2}{*}{\multicolumn{2}{|c|}{ Affordable }} \\
\hline NETWORK & & & \\
\hline HELP & \multirow[t]{2}{*}{$20+$} & \multirow{2}{*}{\multicolumn{2}{|c|}{ Affordable }} \\
\hline DESK & & & \\
\hline MAINTENCE & \multirow{2}{*}{$20+$} & \multirow{2}{*}{\multicolumn{2}{|c|}{ Expensive }} \\
\hline CONTRACT & & & \\
\hline STAFF & \multirow[t]{2}{*}{$20+$} & \multirow{2}{*}{\multicolumn{2}{|c|}{$\begin{array}{l}\text { Very } \\
\text { Affordable }\end{array}$}} \\
\hline TRAINING & & & \\
\hline CAT-5 & \multirow[t]{2}{*}{$1-10$} & \multicolumn{2}{|l|}{ Very } \\
\hline WIRE & & \multicolumn{2}{|l|}{ Affordable } \\
\hline FIBER & \multirow[t]{2}{*}{$11-20+$} & \multirow{2}{*}{\multicolumn{2}{|c|}{ Affordable }} \\
\hline OPTIC & & & \\
\hline SECURE & \multirow[t]{2}{*}{$6-15$} & \multirow{2}{*}{\multicolumn{2}{|c|}{ Expensive }} \\
\hline COMM & & & \\
\hline PROXY & \multirow[t]{2}{*}{$1-10$} & \multirow{2}{*}{\multicolumn{2}{|c|}{ Affordable }} \\
\hline SERVER & & & \\
\hline WINDOWS & \multirow[t]{2}{*}{$1-10$} & \multirow{2}{*}{\multicolumn{2}{|c|}{$\begin{array}{l}\text { Very } \\
\text { Affordable }\end{array}$}} \\
\hline SOFTWARE & & & \\
\hline VOICE & \multirow[t]{2}{*}{$11-20+$} & \multirow{2}{*}{\multicolumn{2}{|c|}{ Affordable }} \\
\hline COMM & & & \\
\hline ANTI-VIRUS & \multirow[t]{2}{*}{$20+$} & \multirow{2}{*}{\multicolumn{2}{|c|}{$\begin{array}{l}\text { Very } \\
\text { Affordable }\end{array}$}} \\
\hline SOFTWARE & & & \\
\hline LAN & \multirow[t]{2}{*}{$11-20$} & \multirow{2}{*}{\multicolumn{2}{|c|}{ Affordable }} \\
\hline SOFTWARE & & & \\
\hline LAN-WAN & \multirow[t]{2}{*}{$11-20$} & \multirow{2}{*}{\multicolumn{2}{|c|}{$\begin{array}{l}\text { Affordable } \\
\text { Expensive }\end{array}$}} \\
\hline SOFTWARE & & & \\
\hline
\end{tabular}


APPENDIX D

THE FUTURE OF TECHNOLOGY INFRASTRUCTURE IN WEST VIRGINIA HIGH SCHOOLS

ROUND 2

DATA SHEETS 
MEAN ROUND2 RESULTS - LIFE EXPECTANCY

TECH Net Palm Wire Lap Elect File Shar NoW Swit Help Main Staff CAT- Fiber Sec Prox Wind Voic Anti Lan Lan Hub Compless CompWhB Serv Netw Net Net Desk Cont Train 5Wir Optic Com Serv Soft Com Virus Soft Wan EXPERT

\begin{tabular}{|c|c|c|c|c|c|c|c|c|c|c|c|c|c|c|c|c|c|c|c|c|c|}
\hline A & 4 & 4 & 4 & 3 & 3 & 4 & 4 & 3 & 4 & 5 & 3 & 3 & 5 & 3 & 4 & 4 & 5 & 4 & 4 & 4 & 4 \\
\hline B & 4 & 4 & 1 & 1 & 5 & 1 & 4 & 1 & 5 & 1 & 1 & 1 & 4 & 4 & 1 & 3 & 3 & 1 & 1 & 1 & 1 \\
\hline C & 5 & 1 & 1 & 1 & 3 & 2 & 5 & 1 & 3 & 1 & 1 & 1 & 4 & 1 & 4 & 4 & 3 & 1 & 1 & 1 & \\
\hline D & 4 & 5 & 5 & 4 & 4 & 2 & & 2 & 4 & 1 & 1 & 1 & 5 & 4 & & 4 & 5 & 4 & 3 & 4 & \\
\hline$E$ & 3 & 5 & 4 & 1 & 5 & 1 & 1 & 5 & 4 & 1 & 1 & 1 & 4 & 3 & 4 & 4 & 1 & 5 & 1 & 2 & \\
\hline $\mathbf{F}$ & 5 & 3 & 3 & 2 & 4 & 3 & 4 & 3 & 5 & 2 & 1 & 1 & 5 & 4 & & 5 & 4 & 3 & 1 & 3 & \\
\hline G & 4 & 2 & 2 & 1 & 3 & 2 & 2 & 1 & 3 & 3 & 3 & 1 & 4 & 3 & 4 & 4 & 3 & 2 & 2 & 3 & \\
\hline H & 4 & 3 & 3 & 4 & 4 & 4 & 3 & 2 & 4 & 4 & 1 & 2 & 4 & 3 & 3 & 3 & 4 & 4 & 1 & 3 & \\
\hline I & 4 & 4 & 5 & 4 & 4 & 3 & 5 & 4 & 4 & 1 & 3 & 1 & 3 & 1 & 3 & 4 & 4 & 4 & 5 & 5 & \\
\hline $\mathbf{J}$ & 4 & 3 & 2 & 2 & 2 & 5 & 3 & 2 & 4 & 2 & 2 & 1 & 3 & 2 & 2 & 4 & 4 & 2 & 3 & 4 & \\
\hline K & 5 & 1 & & 1 & 1 & 1 & 1 & 1 & 1 & 1 & 1 & 1 & & 1 & 4 & 1 & 1 & 1 & 1 & 1 & \\
\hline L & 5 & 3 & 2 & 4 & 4 & 3 & 2 & 1 & 3 & 1 & 1 & 1 & 4 & 4 & 2 & 4 & 5 & 3 & 4 & 3 & \\
\hline M & 2 & 1 & 2 & 1 & 5 & 1 & 1 & 2 & 1 & 2 & 1 & 1 & 4 & 1 & 2 & 4 & 3 & 1 & 1 & 1 & \\
\hline $\mathbf{N}$ & 4 & 3 & 3 & 3 & 3 & 1 & 3 & 1 & 1 & 1 & 1 & 1 & 3 & 1 & 4 & 5 & 4 & 1 & 1 & 3 & \\
\hline 0 & 4 & 5 & 5 & 4 & 5 & 3 & 3 & 3 & 5 & 1 & 3 & 1 & 4 & 4 & 3 & 4 & 4 & 4 & 4 & 4 & \\
\hline $\mathbf{P}$ & 3 & 3 & 1 & 1 & 4 & 3 & 3 & 3 & 4 & 3 & 3 & 1 & 5 & 1 & 1 & 4 & 4 & 2 & 3 & 3 & \\
\hline $\mathbf{Q}$ & 3 & 5 & 5 & 5 & 3 & 2 & 2 & 2 & 2 & 1 & 1 & 1 & 4 & 1 & 2 & 2 & 5 & 3 & 3 & 3 & \\
\hline $\mathbf{R}$ & 1 & 3 & 3 & 3 & 3 & 1 & 1 & 1 & 3 & 1 & 1 & 1 & 3 & 2 & 1 & 4 & 3 & 1 & 1 & 1 & 1 \\
\hline Mean R2 & 3.78 & 3.22 & 3.00 & 2.50 & 3.61 & 2.33 & 2.76 & 2.11 & 3.33 & 1.78 & 1.61 & 1.17 & 4.00 & 2.39 & 2.75 & 3.72 & 3.61 & 2.56 & 2.22 & 2.72 & 2.61 \\
\hline Std. Dev. & 1.03 & 1.31 & 1.41 & 1.38 & 1.06 & 1.20 & 1.31 & 1.15 & 1.29 & 1.18 & 0.89 & 0.50 & 0.69 & 1.25 & 1.15 & 0.93 & 1.16 & 1.34 & 1.36 & 1.24 & 1.06 \\
\hline CATEG. & 4 & 3 & 5 & 1 & 3 & 1 & 3 & 1 & 4 & 1 & 1 & 1 & 4 & 1 & 4 & 4 & 4 & 1 & 1 & 3 & \\
\hline Low Limit & 3 & 2 & 2 & 2 & 3 & 2 & 2 & 1 & 3 & 1 & 1 & 1 & 4 & 2 & 2 & 3 & 3 & 2 & 1 & 2 & \\
\hline Up Limit & 4 & 4 & 4 & 3 & 4 & 3 & 4 & 3 & 4 & 2 & 2 & 1 & 4 & 3 & 3 & 4 & 4 & 3 & 3 & 3 & \\
\hline
\end{tabular}

$\begin{array}{lrrrrrrrrrrrrrrrrrrrrr}\text { \# of 1 } & 1 & 3 & 3 & 7 & 1 & 6 & 4 & 7 & 3 & 11 & 12 & 16 & 0 & 7 & 3 & 1 & 2 & 6 & 9 & 5 & 4 \\ \text { \# of 2 } & 1 & 1 & 4 & 2 & 1 & 4 & 3 & 5 & 1 & 3 & 1 & 1 & 0 & 2 & 4 & 1 & 0 & 3 & 1 & 1 & 3 \\ \text { \# of 3 } & 3 & 7 & 4 & 3 & 6 & 5 & 5 & 4 & 4 & 2 & 5 & 1 & 4 & 4 & 3 & 2 & 5 & 3 & 4 & 7 & 7 \\ \text { \# of 4 } & 9 & 3 & 2 & 5 & 6 & 2 & 3 & 1 & 7 & 1 & 0 & 0 & 9 & 5 & 6 & 12 & 7 & 5 & 3 & 4 & 4 \\ \text { \# of 5 } & 4 & 4 & 4 & 1 & 4 & 1 & 2 & 1 & 3 & 1 & 0 & 0 & 4 & 0 & 0 & 2 & 4 & 1 & 1 & 1 & 0 \\ & & & & & & & & & & & & & & & & & & & & & \end{array}$

$\begin{array}{llllllllllllllllllllll}\text { Total } & 18 & 18 & 17 & 18 & 18 & 18 & 17 & 18 & 18 & 18 & 18 & 18 & 17 & 18 & 16 & 18 & 18 & 18 & 18 & 18 & 18\end{array}$ 


\section{MEANROUNDR RESULTS- AFFORDABIUTY}

TECH Net PalmWre Lap Eect Fle Shar NoW Swit Help Main Staff CAT-Fiber Sec Prox Wind Voic Anti Lan Lan Hub Compless Com WhB Serv Netw Net Net Desk Cont Train 5Wir Optic Com Serv Soft Com Virus Soft Wan

\begin{tabular}{|c|c|c|c|c|c|c|c|c|c|c|c|c|c|c|c|c|c|c|c|c|c|}
\hline EXPERT & & & & & & & & & & & & & & & & & & & & & \\
\hline A & 4 & 2 & 3 & 3 & 4 & 4 & 4 & 4 & 4 & 4 & 4 & 4 & 5 & 4 & 4 & 4 & 5 & 4 & 5 & 4 & 4 \\
\hline B & 6 & 3 & 3 & 3 & 3 & 4 & 4 & 3 & 4 & 4 & 4 & 4 & 5 & 5 & 3 & 2 & 6 & 3 & 6 & 3 & 3 \\
\hline C & 5 & 3 & 3 & 2 & 4 & 4 & 5 & 1 & 3 & 3 & 3 & 4 & 4 & 3 & 3 & 5 & 5 & 4 & 6 & 4 & 4 \\
\hline D & 4 & 4 & 4 & 4 & 4 & 6 & 4 & 4 & 4 & 3 & 4 & 6 & 4 & 6 & 4 & 4 & 4 & 4 & 6 & 4 & 4 \\
\hline$E$ & 4 & 3 & 3 & 4 & 1 & 6 & 5 & 3 & 4 & 5 & 5 & 4 & 5 & 3 & 2 & 5 & 6 & 4 & 6 & 5 & 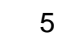 \\
\hline$F$ & 3 & 1 & 3 & 3 & 1 & 3 & 4 & 1 & & 3 & 3 & 6 & 5 & 4 & & 4 & 6 & 1 & 4 & 4 & 4 \\
\hline G & 4 & 2 & 2 & 2 & 5 & 4 & 3 & 1 & 3 & 3 & 2 & 6 & 5 & 5 & 3 & 3 & 3 & 2 & 6 & 3 & 3 \\
\hline H & 3 & 3 & 3 & 3 & 3 & 4 & 4 & 3 & 3 & 3 & 2 & 2 & 3 & 2 & 3 & 3 & 4 & 3 & 4 & 4 & 3 \\
\hline I & 3 & 4 & 2 & 3 & 4 & 6 & 6 & 3 & 3 & 6 & 3 & 6 & 5 & 4 & 2 & 5 & 4 & 4 & 5 & 5 & 5 \\
\hline $\mathbf{J}$ & 6 & 2 & 3 & 4 & 3 & 6 & 6 & 5 & 4 & 5 & 2 & 6 & 6 & 6 & 5 & 5 & 6 & 2 & 4 & 5 & 3 \\
\hline K & 4 & 3 & & 3 & 5 & 4 & 4 & 3 & 4 & 3 & 3 & 3 & 5 & 4 & 3 & 4 & 5 & 4 & 4 & 4 & 1 \\
\hline $\mathbf{L}$ & 5 & 2 & 2 & 4 & 4 & 6 & 6 & 1 & 4 & 6 & 3 & 5 & 6 & 4 & 3 & 4 & 6 & 3 & 6 & 2 & 1 \\
\hline M & 6 & 1 & 2 & 2 & 3 & 6 & 6 & 2 & 4 & 2 & 4 & 6 & 4 & 2 & 2 & 3 & 6 & 6 & 6 & 6 & 5 \\
\hline $\mathbf{N}$ & 6 & 3 & 3 & 4 & 5 & 6 & 6 & 3 & 4 & 3 & 3 & 6 & 6 & 5 & 2 & 4 & 5 & 5 & 6 & 6 & 6 \\
\hline 0 & 6 & 1 & 1 & 2 & 2 & 6 & 6 & 2 & 3 & 2 & 2 & 3 & & 3 & 2 & 4 & 5 & 4 & 5 & 4 & 4 \\
\hline $\mathbf{P}$ & 2 & 3 & 2 & 3 & 3 & 6 & 6 & 3 & 6 & 6 & 4 & 5 & 5 & 4 & 3 & 3 & 4 & 5 & 5 & 5 & 5 \\
\hline $\mathbf{Q}$ & 6 & 1 & 1 & 2 & 3 & 6 & 6 & 3 & 6 & 6 & 6 & 6 & 4 & 3 & 6 & 6 & 4 & 3 & 6 & 6 & 6 \\
\hline $\mathbf{R}$ & 4 & 4 & 4 & 4 & 3 & 4 & 5 & 3 & 5 & 3 & 3 & 3 & 5 & 3 & 3 & 4 & 4 & 4 & 5 & 5 & 5 \\
\hline Mean & 4.50 & 250 & 259 & 3.06 & 3.33 & 5.06 & 5.00 & 267 & 4.00 & 3.89 & 3.33 & 4.72 & 4.82 & 3.89 & 3.12 & 4.00 & 4.89 & 3.61 & 5.28 & 4.39 & 4.28 \\
\hline Std. Dev. & 1.26 & 1.01 & 0.84 & 0.78 & 1.15 & 1.08 & 1.00 & 1.11 & 0.91 & 1.37 & 1.05 & 1.33 & 0.78 & 1.15 & 1.08 & 0.94 & 0.94 & 1.16 & 0.80 & 1.06 & 0.93 \\
\hline & 4 & 3 & 3 & 3 & 3 & 6 & 6 & 3 & 4 & 3 & 3 & 6 & 5 & 4 & 3 & 4 & 6 & 4 & 6 & 4 & 4 \\
\hline Low Limit & 4 & 2 & 2 & 3 & 3 & 4 & 4 & 2 & 4 & 3 & 3 & 4 & 5 & 3 & 3 & 4 & 4 & 3 & 5 & 4 & 4 \\
\hline Up Limit & 5 & 3 & 3 & 3 & 4 & 6 & 6 & 3 & 4 & 5 & 4 & 6 & 5 & 5 & 4 & 4 & 5 & 4 & 6 & 5 & 5 \\
\hline \# of 1 & 0 & 4 & 2 & 0 & 2 & 0 & 0 & 4 & 0 & 0 & 0 & 0 & 0 & 0 & 0 & 0 & 0 & 1 & 0 & 0 & 0 \\
\hline \# of 2 & 1 & 4 & 5 & 5 & 1 & 0 & 0 & 2 & 0 & 2 & 4 & 1 & 0 & 2 & 5 & 1 & 0 & 2 & 0 & 1 & 0 \\
\hline \# of 3 & 3 & 7 & 8 & 7 & 7 & 1 & 1 & 9 & 5 & 8 & 7 & 3 & 1 & 5 & 8 & 4 & 1 & 4 & 0 & 2 & 4 \\
\hline \# of 4 & 6 & 3 & 2 & 6 & 5 & 7 & 6 & 2 & 9 & 2 & 5 & 4 & 4 & 6 & 2 & 8 & 6 & 8 & 4 & 7 & 7 \\
\hline \# of 5 & 2 & 0 & 0 & 0 & 3 & 0 & 3 & 1 & 1 & 2 & 1 & 2 & 9 & 3 & 1 & 4 & 5 & 2 & 5 & 5 & 5 \\
\hline \# of 6 & 6 & 0 & 0 & 0 & 0 & 10 & 8 & 0 & 2 & 4 & 1 & 8 & 3 & 2 & 1 & 1 & 6 & 1 & 9 & 3 & 2 \\
\hline Total & 18 & 18 & 17 & 18 & 18 & 18 & 18 & 18 & 17 & 18 & 18 & 18 & 17 & 18 & 17 & 18 & 18 & 18 & 18 & 18 & 18 \\
\hline
\end{tabular}


APPENDIX E

\section{THE FUTURE OF TECHNOLOGY INFRASTRUCTURE} IN WEST VIRGINIA HIGH SCHOOLS

\section{ROUND 3}

DATA SHEETS 
ROUND 3 RESULTS - LIFE EXPECTANCY

TEC Hub Compless CompWhB Serv Netw Net Net Desk Cont Train 5Wir Optic Com Serv Soft Com Virus Soft Wan EXP

$\begin{array}{llllllllllllllllllllll}\mathbf{A} & 4 & 4 & 4 & 3 & 3 & 4 & 4 & 3 & 4 & 5 & 3 & 3 & 5 & 3 & 4 & 4 & 5 & 4 & 4 & 4 & 4 \\ \mathbf{B} & 4 & 4 & 3 & 3 & 5 & 3 & 3 & 1 & 5 & 1 & 1 & 1 & 4 & 4 & 4 & 4 & 4 & 1 & 1 & 3 & 1 \\ \mathbf{C} & 5 & 1 & 1 & 1 & 3 & 2 & 5 & 1 & 3 & 1 & 1 & 1 & 4 & 1 & 4 & 4 & 3 & 1 & 1 & 1 & 2 \\ \mathbf{D} & 4 & 5 & 5 & 4 & 4 & 2 & & 2 & 4 & 1 & 1 & 1 & 5 & 4 & & 4 & 5 & 4 & 3 & 4 & 4 \\ \mathbf{E} & 3 & 5 & 4 & 1 & 5 & 1 & 1 & 5 & 4 & 1 & 1 & 1 & 4 & 3 & 4 & 4 & 1 & 5 & 1 & 2 & 2 \\ \mathbf{F} & 5 & 3 & 3 & 2 & 4 & 3 & 3 & 3 & 5 & 2 & 1 & 1 & 5 & 4 & 4 & 5 & 4 & 3 & 1 & 3 & 3 \\ \mathbf{G} & 5 & 2 & 2 & 1 & 3 & 2 & 2 & 1 & 3 & 3 & 3 & 1 & 4 & 3 & 4 & 4 & 3 & 2 & 2 & 3 & 3 \\ \mathbf{H} & 4 & 3 & 3 & 4 & 4 & 4 & 3 & 2 & 4 & 4 & 1 & 2 & 4 & 3 & 3 & 3 & 4 & 4 & 1 & 3 & 3 \\ \mathbf{I} & 4 & 4 & 5 & 4 & 4 & 3 & 5 & 4 & 4 & 1 & 1 & 1 & 3 & 1 & 3 & 4 & 4 & 4 & 5 & 5 & 4 \\ \mathbf{J} & 4 & 3 & 2 & 2 & 2 & 5 & 3 & 2 & 4 & 2 & 2 & 1 & 3 & 2 & 2 & 4 & 4 & 2 & 3 & 4 & 3 \\ \mathbf{K} & 5 & 1 & & 1 & 1 & 1 & 1 & 1 & 1 & 1 & 1 & 1 & & 1 & 4 & 1 & 1 & 1 & 1 & 1 & 1 \\ \mathbf{L} & 5 & 3 & 2 & 4 & 4 & 3 & 2 & 1 & 3 & 1 & 1 & 1 & 4 & 4 & 2 & 4 & 5 & 3 & 4 & 3 & 2 \\ \mathbf{M} & 2 & 3 & 2 & 1 & 5 & 1 & 1 & 2 & 1 & 2 & 1 & 1 & 4 & 1 & 2 & 4 & 3 & 1 & 1 & 1 & 1 \\ \mathbf{N} & 4 & 3 & 3 & 3 & 3 & 1 & 3 & 1 & 1 & 1 & 1 & 1 & 3 & 1 & 4 & 5 & 4 & 1 & 1 & 3 & 3 \\ \mathbf{O} & 4 & 5 & 5 & 4 & 5 & 3 & 3 & 3 & 5 & 1 & 3 & 1 & 4 & 4 & 3 & 4 & 4 & 4 & 4 & 4 & 4 \\ \mathbf{P} & 3 & 3 & 1 & 1 & 4 & 3 & 3 & 3 & 4 & 3 & 3 & 1 & 5 & 1 & 1 & 4 & 4 & 2 & 3 & 3 & 3 \\ \mathbf{Q} & 3 & 5 & 5 & 5 & 3 & 2 & 2 & 2 & 2 & 1 & 1 & 1 & 4 & 1 & 2 & 2 & 5 & 3 & 3 & 3 & 3\end{array}$

$\begin{array}{llllllllllllllllllllll}\mathbf{Q} & 3 & 5 & 5 & 5 & 3 & 2 & 2 & 2 & 2 & 1 & 1 & 1 & 4 & 1 & 2 & 2 & 5 & 3 & 3 & 3 & 3 \\ \mathbf{R} & 1 & 3 & 3 & 3 & 3 & 1 & 1 & 1 & 3 & 1 & 1 & 1 & 3 & 2 & 1 & 4 & 3 & 1 & 1 & 1 & 1\end{array}$

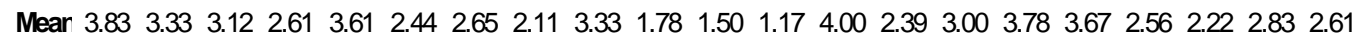

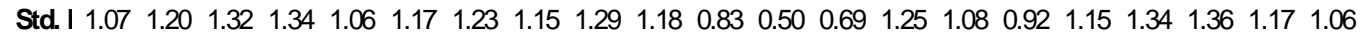

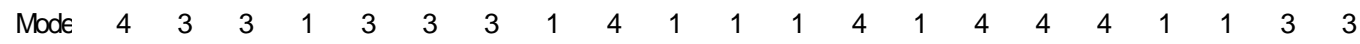

$\begin{array}{llllllllllllllllllllll}\text { Lowl } & 3 & 3 & 2 & 2 & 3 & 2 & 2 & 1 & 3 & 1 & 1 & 1 & 4 & 2 & 2 & 3 & 3 & 2 & 1 & 2 & 2 \\ \text { UpLi } & 4 & 4 & 4 & 3 & 4 & 3 & 3 & 3 & 4 & 2 & 2 & 1 & 4 & 3 & 4 & 4 & 4 & 3 & 3 & 4 & 3\end{array}$

\#\#\#

Response

MEN Hub Compless CompWhB Serv Netw Net Net Desk Cont Train 5Wir Optic Com Serv Soft Com Virus Soft Wan

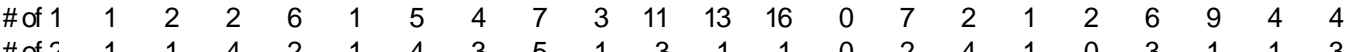

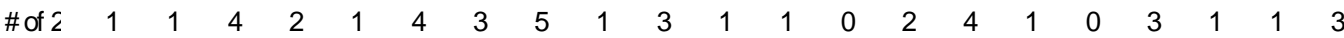
$\begin{array}{llllllllllllllllllllll}\text { \# of } こ & 3 & 8 & 5 & 4 & 6 & 6 & 7 & 4 & 4 & 2 & 4 & 1 & 4 & 4 & 3 & 1 & 4 & 3 & 4 & 8 & 7\end{array}$ $\begin{array}{llllllllllllllllllllll}\text { \# of } 4 & 8 & 3 & 2 & 5 & 6 & 2 & 1 & 1 & 7 & 1 & 0 & 0 & 9 & 5 & 8 & 13 & 8 & 5 & 3 & 4 & 4 \\ \text { \# of } 5 & 5 & 4 & 4 & 1 & 4 & 1 & 2 & 1 & 3 & 1 & 0 & 0 & 4 & 0 & 0 & 2 & 4 & 1 & 1 & 1 & 0\end{array}$ $\begin{array}{llllllllllllllllllllll}\text { Total } & 18 & 18 & 17 & 18 & 18 & 18 & 17 & 18 & 18 & 18 & 18 & 18 & 17 & 18 & 17 & 18 & 18 & 18 & 18 & 18 & 18\end{array}$ 


\section{ROUND 3 RESULTS - AFFORDABILITY}

TEC Hub Compless CompWhB Serv Netw Net Net Desk Cont Train 5Wir Optic Com Serv Soft Com Virus Soft Wan

EXP

\begin{tabular}{|c|c|c|c|c|c|c|c|c|c|c|c|c|c|c|c|c|c|c|c|c|c|}
\hline A & 4 & 2 & 3 & 3 & 4 & 4 & 4 & 4 & 4 & 4 & 4 & 4 & 5 & 4 & 4 & 4 & 5 & 4 & 5 & 4 & 4 \\
\hline B & 2 & 3 & 3 & 2 & 3 & 6 & 2 & 4 & 3 & 3 & 4 & 4 & 4 & 5 & 4 & 6 & 4 & 6 & 4 & 4 & 2 \\
\hline C & 5 & 3 & 3 & 2 & 4 & 4 & 5 & 1 & 3 & 3 & 3 & 4 & 4 & 3 & 3 & 5 & 5 & 4 & 6 & 4 & 4 \\
\hline E & 4 & 4 & 4 & 4 & 4 & 6 & 4 & 4 & 4 & 3 & 4 & 6 & 4 & 6 & 4 & 4 & 4 & 4 & 6 & 4 & \\
\hline E & 4 & 3 & 3 & 4 & 1 & 6 & 5 & 3 & 4 & 5 & 5 & 4 & 5 & 3 & 2 & 5 & 6 & 4 & 6 & 5 & \\
\hline $\mathbf{F}$ & 3 & 3 & 3 & 3 & 6 & 6 & 2 & 4 & 3 & 3 & 6 & 1 & 4 & 3 & 4 & 6 & 4 & 6 & 4 & 4 & \\
\hline G & 4 & 2 & 2 & 2 & 5 & 4 & 3 & 1 & 3 & 3 & 2 & 6 & 5 & 5 & 3 & 3 & 3 & 2 & 6 & 3 & \\
\hline H & 3 & 3 & 3 & 3 & 3 & 4 & 4 & 3 & 3 & 3 & 2 & 2 & 3 & 2 & 3 & 3 & 4 & 3 & 4 & 4 & \\
\hline I & 2 & 4 & 2 & 3 & 6 & 6 & 6 & 3 & 3 & 6 & 3 & 6 & 5 & 4 & 2 & 6 & 4 & 6 & 5 & 5 & \\
\hline $\mathbf{J}$ & 6 & 2 & 3 & 4 & 3 & 6 & 6 & 5 & 4 & 5 & 2 & 6 & 6 & 6 & 5 & 5 & 6 & 2 & 4 & 5 & \\
\hline K & 4 & 3 & & 3 & 5 & 4 & 4 & 3 & 4 & 3 & 3 & 3 & 5 & 4 & 3 & 4 & 5 & 4 & 4 & 4 & \\
\hline L & 5 & 2 & 2 & 4 & 4 & 6 & 6 & 1 & 4 & 6 & 3 & 5 & 6 & 4 & 3 & 4 & 6 & 3 & 6 & 2 & 4 \\
\hline M & 6 & 1 & 3 & 2 & 3 & 6 & 6 & 2 & 4 & 2 & 6 & 6 & 4 & 2 & 2 & 6 & 6 & 6 & 6 & 4 & 2 \\
\hline $\mathbf{N}$ & 6 & 3 & 3 & 4 & 5 & 6 & 6 & 3 & 4 & 3 & 3 & 6 & 6 & 5 & 2 & 4 & 5 & 5 & 6 & 6 & \\
\hline 0 & 6 & 1 & 1 & 2 & 2 & 6 & 6 & 2 & 3 & 2 & 2 & 3 & & 3 & 2 & 4 & 5 & 4 & 5 & 4 & \\
\hline $\mathbf{P}$ & 2 & 3 & 2 & 3 & 3 & 6 & 6 & 3 & 6 & 6 & 4 & 5 & 5 & 4 & 3 & 3 & 4 & 5 & 5 & 5 & \\
\hline $\mathbf{Q}$ & 6 & 1 & 1 & 2 & 3 & 6 & 6 & 3 & 6 & 6 & 6 & 6 & 4 & 3 & 6 & 6 & 4 & 3 & 6 & 6 & \\
\hline R & 4 & 4 & 4 & 4 & 3 & 4 & 5 & 3 & 5 & 3 & 3 & 3 & 5 & 3 & 3 & 4 & 4 & 4 & 5 & 5 & \\
\hline Mear & 4.22 & 2.61 & 2.65 & 3.00 & 3.72 & 5.33 & 4.78 & 2.89 & 3.89 & 3.83 & 3.61 & 4.44 & 4.71 & 3.83 & 3.22 & 4.56 & 4.67 & 4.17 & & & 3.94 \\
\hline Std. I & 1.40 & 0.95 & 0.84 & 0.82 & 1.28 & 0.94 & 1.36 & 1.10 & 0.94 & 1.38 & 1.34 & 1.54 & 0.82 & 1.17 & 1.08 & 1.07 & 0.88 & 1.26 & 0.83 & 0.94 & 1.22 \\
\hline & 4 & 3 & 3 & 3 & 3 & 6 & 6 & 3 & 4 & 3 & 3 & 6 & 5 & 3 & 3 & 4 & 4 & 4 & 6 & 4 & 4 \\
\hline Lowl & 3 & 2 & 2 & 3 & 3 & 5 & 4 & 2 & 3 & 3 & 3 & 3 & 4 & 3 & 3 & 4 & 4 & 3 & 5 & 4 & \\
\hline UpL & 5 & 3 & 3 & 3 & 5 & 6 & 6 & 3 & 4 & 5 & 4 & 5 & 5 & 5 & 4 & 5 & 5 & 5 & 6 & 5 & \\
\hline
\end{tabular}

??? Hub Compless ComphhB Serv Netw Net Net Desk Cont Train 5Wir Optic Com Serv Soft Com Virus Soft Wan $\begin{array}{llllllllllllllllllllll}\# \text { of } 1 & 0 & 3 & 2 & 0 & 1 & 0 & 0 & 3 & 0 & 0 & 0 & 1 & 0 & 0 & 0 & 0 & 0 & 0 & 0 & 0 & 0\end{array}$ $\begin{array}{lllllllllllllllllllllll}\text { \# of } c & 3 & 4 & 4 & 6 & 1 & 0 & 2 & 2 & 0 & 2 & 4 & 1 & 0 & 2 & 5 & 0 & 0 & 2 & 0 & 1 & 3\end{array}$ \# of $\begin{array}{llllllllllllllllllllll} & 2 & 8 & 9 & 6 & 7 & 0 & 1 & 8 & 7 & 9 & 6 & 3 & 1 & 6 & 7 & 3 & 1 & 3 & 0 & 1 & 3\end{array}$ $\begin{array}{llllllllllllllllllllll}\# \text { \# of } 4 & 6 & 3 & 2 & 6 & 4 & 6 & 4 & 4 & 8 & 1 & 4 & 4 & 6 & 5 & 4 & 7 & 8 & 7 & 5 & 9 & 6\end{array}$

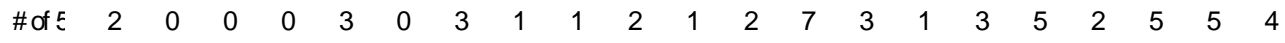

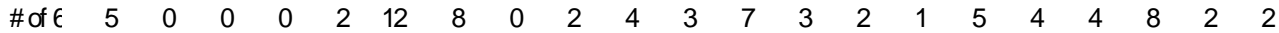
$\begin{array}{llllllllllllllllllllll}\text { Total } & 18 & 18 & 17 & 18 & 18 & 18 & 18 & 18 & 18 & 18 & 18 & 18 & 17 & 18 & 18 & 18 & 18 & 18 & 18 & 18 & 18\end{array}$ 
27 Fairlawn Drive

PO Box 2575

Buckhannon, WV 26201

Whcarman@msys.net

\section{VITA}

\section{WilliamH.Carman}

I was a county superintendent during 1993-1997. It is a role that I found to challenging and allowed me to have some impact on the educational system of West Virginia. My main goal is to help direct the county system I am employed by to reach its greatest potential and thus provide the students the best education possible.

\section{Employment}

1997-present Upshur County Schools

Buckhannon, WV

Principal, Buckhannon-Upshur High School

- $\quad$ Created a positive financial environment.

- $\quad$ Supported active Faculty Senate and Local School Improvement Council.

- Worked with staff and community to revise the curriculum.

- Established a disciplinary climate which fosters a safer school.

- $\quad$ Prioritized student achievement.

1993-1997 Superintendent of Schools

Wayne, WV

- $\quad$ Planned and constructed an $\$ 18$ million dollar high school.

- $\quad$ Planned and implemented technology in the Wayne County Schools.

- $\quad$ Took responsibility for a $\$ 40$ million budget which was never in deficit.

- Lead Wayne County to a position of prominence among WV school systems.

- Passed a $100 \%$ levy and refinanced a bond to gain $\$ 1.1$ million.

- Constructed a state of the art technology academic center.

- CEO - school system having 8,000 students, five high schools, 6 middle schools,

- 12 elementary schools, a staff of 1,000 , and a budget of $\$ 40$ million.

1988-1993 Ohio County Schools Wheeling, WV

Assistant Principal, Wheeling Park High School

- Responsible for curriculum and 2,000 student schedules. .

- Directed guidance department of six counselors.

- Acted as a laison to 120 teachers, 2,000 students and their parents. 
1983-1988 Ohio County Schools Wheeling, WV

Director of Computer Services

- Created the administrative computer system.

- Maintained computer network with four middle schools and high

school.

- $\quad$ Supported instructional computing at school sites.

- Worked with vocational computer network.

- Served as the county computer programmer.

1966-1983 Ohio County Schools Wheeling,

WV

Mathematics Teacher

- $\quad$ Served as Department Chair at Wheeling Park High.

- $\quad$ Served as Department Chair at Triadelphia High.

- $\quad$ Taught math and physical education at West Liberty Jr. High

\section{Education}

1996-1999 CEO Cohort Doctoral Program Courses completed with a 3.9 G.P.A. Comprehensive Exams completed. Dissertation is being written. West Virginia University.

1971 Master of Science Mathematics West Virginia University

1970 Master of Arts School Administration West Virginia University

1966 Bachelor of Arts Secondary Education ( Math and P.E. teaching fields) West Liberty State College

\section{Interests}

High school and college athletics, model railroading ho scale, carpentry projects, and traveling.

\section{Organizations}

Co-chair for Western T-Pad Executive Committee Board of Directors Huntington Area Chamber of Commerce Board of Directors WVASA Region II Representative (2 terms)

Advisory Council WVEIS for superintendents Regional member Marshall Community College Consortium Member Wayne County Economic Development Council

Past President RESA II Board of Directors

Member Policy 2510 Revision Team

Member Accreditation Standards Revision Team

Co-director Upshur County School-to-Work

Member Buckhannon Rotary Club

Member Chapel Hill United Methodist Church 